\title{
The Donation Booth: Mandating Donor Anonymity to Disrupt the Market for Political Influence
}

\author{
Ian Ayres* and Jeremy Bulow**
}

In this article, Professors Ayres and Bulow argue that, instead of mandating disclosure of all campaign contributions, we should instead consider mandating that all contributions be anonymous. Just as the secret ballot makes it more difficult for candidates to buy votes, mandating anonymous donations can make it more difficult for candidates to sell access or influence. Forcing donors to funnel campaign contributions through blind trusts can discourage quid pro quo corruption because candidates never learn whether particular donors paid the price. To implement their proposal, the authors articulate a mimicry principle that would allow faux donors to send the same signals as real donors. Talk is cheap; just as anyone can say they voted for Clinton, anyone-including faux donors-could claim they donated money. Mandating donor anyonymity is also more clearly consitutional than several alternative reforms. In a world in which the free speech burdens of the voting booth and mandated disclosure are constitutional (because of their impact on corruption), a properly structured "donation booth" is a fortiori constitutional. Mandated anonymity, however, is not a panaced. This reform would predictably shift money toward less accountable "issue advocacy" expenditures and may be so effective in disrupting the market for influence that it cripples candidates' ability to raise funds. Even considering these unintended effects, the article suggests that forms of mandated anonymity might usefully compliment other campaign finance restrictions.

[T] he principle of equal consideration is a moral orientation so fundamental that it is hard to see how one might go about the task of demonstrating its validity to an adversary. Fortunately, the principle itself is widely accepted.

-Robert A. Dahl ${ }^{1}$

*William K. Townsend Professor, Yale Law School. ayres@mail.law.yale.edu.

** Richard Stepp Professor of Economics, Graduate School of Business, Stanford University. bulow_jeremy@gsb.stanford.edu.

Bruce Ackerman, Jennifer Brown, Tom Campbell, Joshua Cohen, Steve Gotlieb, Peter Harris, John Langbein, Larry Lessig, John Lott, Bob Munch, Richard Posner, Jay Pottenger, E. Joshua Rosenkranz, Steve Ross, Ian Shapiro, Victor Stone, David Strauss, Kathleen Sullivan, Cass Sunstein, Tom Ulen, Fred Wertheimer, and seminar participants at the American Bar Foundation and the University of Chicago provided helpful comments. Sarah Goddard and Andrea Rottinger provided excellent research assistance. 
I think it's disingenuous for anybody in public life to say that it doesn't help you to be considered for [a trade mission] if you help the person who happens to win an election.... And it is a good thing to do. That's the way-that's the way the political system works.

-President William Jefferson Clinton ${ }^{2}$

\section{INTRODUCTION}

The privacy of the voting booth is now a core feature of our democracy. But surprisingly, the secret ballot only became firmly entrenched in America toward the end of the nineteenth century. "Before this reform, people could buy your vote and hold you to your bargain by watching you at the polling place."3 Voting booth privacy disrupted the economics of vote buying, making it much more difficult for candidates to buy votes because, at the end of the day, they could never be sure who voted for them.

We can harness similar benefits by creating a "donation booth": a screen that forces donors to funnel campaign contributions through blind trusts. Like the voting booth, the donation booth would keep candidates from learning the identity of their supporters. Mandating anonymous donations through a system of blind trusts would make it harder for candidates to sell access or influence because they would never know which donors had paid the price.

Knowledge about whether the other side actually performs his or her promise is an important prerequisite for trade. People-including political candidates-are less likely to deal if they are uncertain whether the other side performs. By keeping political candidates ignorant of their donors' identities, we can disrupt the "influence selling" market just as voting booth privacy disrupts the "vote buying" market.

The idea that donor anonymity might reduce corruption is not new to this article. $^{4}$ Indeed, several states have already experimented with prohibiting

1. ROBERT A. DAHL, DEMOCRACY, LIBERTY AND EQUALITY 216 (1986). Dahl defines the principle of equal consideration in the negative: "No distribution of socially allocated [goods] is acceptable if it violates the principle that the good or interest of each human being is entitled to equal consideration." Id. at 217.

2. Clinton's Opening Statement and Responses at His News Conference, N.Y. TIMES, Mar. 8, 1997, at A8 [hereinafter Clinton's Opening Statement].

3. Bruce Ackerman, Crediting the Voters: A New Beginning for Campaign Finance, 13 AM. PROSPECT 71, 71 (1993); see also Ashley C. Wall, The Money of Politics: Financing American and British Elections, 5 TUL. J. INT'L \& COMP. L. 489, 503 (1997) (commenting that the Ballot Act of 1872 "brought into existence the secret ballot, which had long term effects on curbing bribery").

4. In the process of researching this piece, we have found a host of prior or independent contemporaneous proponents of the idea. See, e.g., Saul Levmore, The Anonymity Tool, 144 U. PA. L. REV. 2191, 2222 (1996) ("It should not be surprising to find a system that made political contributions anonymous by channeling them to candidates through intermediaries . . . .'); James R. Atwood, To End Dollars for Access Make All Campaign Contributions Anonymous, LEGAL TIMES, Sept. 22, 1997, at 27 (stating that, to achieve true campaign finance reform, we "must be able to lie 
judicial candidates from learning who donates to their (re)election campaigns. The rationale, of course, is that judges don't need to know the identity of their donors: Judicial decisions should be based on cases' merits, not contributors' money. But there is no good reason why legislators or the executive needs to know the identity of their donors. An individual's power to influence government should not turn on personal wealth. Small donors are already effectively anonymous because $\$ 100$ isn't going to buy very much face time with the President. ${ }^{5}$ Mandating anonymity is likely to level the influence playing field by making small contributions count for relatively more. Anonymous donors can still signal the intensity of their preferences by marching on Washington-barefoot, if need be.

In what has become a postelection ritual, politicians wring their hands about the problem of campaign donors buying unwarranted "access." Can-

about whether we gave at the office"); Gary Hom, Letter to the Editor, Legislator's Passion Tends to Be Partisan, N.Y. TMIES, Apr. 13, 1997, at 14 (advocating donor anonymity); Sir Geoffrey Pattie, Letter to the Editor, People's Right to Donate Anonymously, FIN. TMMES, Nov. 19, 1997, at A26; Wayne Rigby, Letter to the Editor, Call Donors' Bluff, N.Y. TIMEs, Apr. 13, 1997, at 14 (advocating donor anonymity). Newspaper op-eds discussing our proposal have also uncovered additional preexisting proponents. For example, after Arianna Huffington wrote a syndicated column touting our proposal, see Arianna Huffington, Anonymity Takes Sleaze out of Fund-Raising, CHI. SUN-TIMES, Oct. 5, 1997, at 42, Sidney J. Goldfarb, a 1997 candidate for the New Jersey State Assembly, wrote one of us a letter saying that making campaign donations anonymous had been one of his campaign proposals. See Letter from Sidney J. Goldfarb to Ian Ayres (Oct. 21, 1997) (on file with the Stanford Law Review); see also Fred Hiatt, Campaign Finance: The Anonymous Donor Plan, WASH. POST, Nov. 2, 1997, at C7 (discussing this article and mentioning that Marc Geffroy, a commercial real estate executive, had written to the Washington Post with a similar idea). Paul Carrington also independently proposed mandated anonymity at a Brennan Center Conference on campaign finance in October 1997. See Letter from E. Joshua Rosenkranz, Executive Director, Brennan Center for Justice, to Ian Ayres (Nov. 5, 1997) (on file with the Stanford Law Review). Moreover, the anticorruption benefits of donor anonymity were explicitly understood by the Office of Government Ethics ("OGE") in 1993 when it proposed requiring anonymous donations for presidential legal defense funds. See text accompanying notes 24-25 infra; see also Michael W. McConnell, A Constitutional Campaign Finance Plan, WALL ST. J., Dec. 11, 1997, at A22 ("A more radical proposal is to create a mechanism for anonymous contributions above the ordinary legal limit. If a candidate does not know who made the contribution, then there is no possibility of improper influence."). We have not, however, been able to document examples of other countries requiring donor anonymity. See generally CENTER FOR RESPONSIVE POLITICS, THE WORLD OF CAMPAIGN FINANCE: A READER'S GUIDE TO THE FUNDING OF INTERNATIONAL ELECTIONS (1993).

In light of these preexisting and concurrent proposals, the contribution of this article, if any, is in detailing the ways donor anonymity could be implemented effectively and discussing why donor anonymity is constitutional.

5. The current $\$ 3$ checkoff on tax returns is an extreme example. See Editorial, Soft Money Swamps Tax Checkoff, LEDGER (Lakeland, Fla.), Apr. 15, 1997, at A10 (describing the tax checkoff). The contributors are anonymous because candidates cannot verify whether they checked the box or not. Therefore, a taxpayer who says to President Clinton, "I effectively gave you about $\$ 1.30$ by earmarking $\$ 3$ of my taxes to the presidential campaign fund," should not expect much additional attention, even if her statement could be made credibly. 
didates claim that contributions do not affect their political positions. ${ }^{6}$ Nonetheless, the suspicion that "access" leads to corruption persists. If candidates really want to stop themselves from selling influence or access, they should forego finding out the identity of their contributors.

The idea of mandating anonymity at first strikes many readers as a radical and dangerous departure from our culture of disclosure. The metaphors of "sunshine" and "open air" are currently very powerful. But to assess the anonymity idea fairly, it is necessary to free ourselves from what might be little more than the happenstance of history. Saul Levmore notes that participants in disclosure and anonymity regimes cling rather arbitrarily to the status quo:

It is common for a faculty member accustomed to open voting to deride secret ballots, especially in votes on promotion, as cowardly and dangerously hospitable to inappropriate motives, while faculty accustomed to closed voting abhor open voting as an example of overdelegation to committees and unsuitable empowerment of deans and regard it as adding to the difficulty of maintaining standards of excellence. ${ }^{7}$

The public ballot was similarly accepted as a natural and necessary part of democracy for roughly half of our nation's history. ${ }^{8}$ This system produced "the common spectacle of lines of persons being marched to the polls holding their colored ballots above their heads to show that they were observing orders or fulfilling promises." 9 These spectacles put such pressure

6. See PAUL H. DOUGLAS, ETHICS IN GOVERNMENT 44 (1952) ("[T]he official will claimand may indeed believe-that there is no causal connection between the favors he has received and the decisions which he makes."); see also Clinton's Opening Statement, supra note 2, at A8 ("I don't believe you can find any evidence . . . that I . . . changed government policy solely because of a contribution.").

7. Levmore, supra note 4 , at 2222-23.

8. In England, John Stuart Mill supported nonanonymous voting. See JOHN STUART MILL, CONSIDERATIONS ON REPRESENTATIVE GOVERNMENT 154-58 (Currin V. Shields ed., 1958).

9. Wayne Andrews, Voting, in CONCISE DICTIONARY OF AMERICAN HISTORY 989 (Wayne Andrews ed., 1962); see also Philip E. Converse, Change in the American Electorate, in THE Human Meaning of Social Change 263, 277 (Angus Campbell \& Philip E. Converse eds., 1972). Converse writes:

The several states of the new republic had moved rather rapidly at the beginning of the nineteenth century from ancient methods of voice voting ('viva-voce' voting) to paper ballots.... [T] he parties took extraordinary measures to differentiate their ballots-in color of paper, flamboyant designs, and the like-to assure that the voter's choice would be apparent to anybody witnessing his submission to the ballot box and, indeed, would typically be visible from across the street.

Id.

The thesis that the Australian ballot was adopted in order to deter vote buying specificallyand cleanse the political system generally-is hotly contested. An alternative interpretation is that these voting reforms were motivated, at least in part, to dampen mass political activism. The "spectacle" of lines of voters marching to the polls with colored ballots in hand might not have indicated that their votes were bought, but instead that their votes were not for sale-a symbol of the solidarity between voters and labor or other mass political movements. See, e.g., MICHAEL E. MCGETT, THE DECLINE OF POPULAR POLITICS: THE AMERICAN NORTH 1865-1928, at 12 (1986); Walter Dean Burnham, The Changing Shape of the American Political Universe, 59 AM. POL. SCI. 
on the disclosure norm that, ultimately, the secret "Australian ballot" caught on and spread like wildfire at the end of the nineteenth century. ${ }^{10}$ We ask readers to consider with us whether the current spectacle of campaign corruption might be sufficient to overturn our deeply ingrained disclosure norm.

This essay will show in some detail how a system of blind trusts might be structured to ensure donor anonymity. We will respond to two key objections:

(1) The proposal will be ineffective in disrupting the market for political influence because donors will find credible ways to signal the size of their donations.

(2) The proposal will be too effective in disrupting the market for political influence because it will make it too hard for candidates to raise campaign donations. ${ }^{11}$

The first objection suggests that mandated anonymity would not significantly reduce donations, whereas the second objection suggests that overall donations would plummet. A major task of this essay, then, is to assess whether mandating anonymity could effectively deter donors from trying to purchase access or influence. Some candidates would undoubtedly find ways to identify some donors, and some donors would undoubtedly make themselves known by switching to independent expenditures. In the end, however, we predict that mandating donor anonymity would substantially reduce the number of six-figure donations. Just as the secret ballot reduced the amount of voting, ${ }^{12}$ mandated donor anonymity is likely to reduce political giving.

Of course, the predicted reduction in large-scale contributions leads to the second objection. Some will argue that campaign speech is already underfunded and that mandating anonymity will only exacerbate the problem.

REV. 7 (1965). Even if this alternative reading of the Australian ballot is correct, our response is that the donation booth has the potential to dampen the political power of those with disproportionate wealth and thereby increase the incentives for wider popular politics.

10. See John H. Wigmore, The Australian Ballot System as Embodied IN the LEGISLATION OF VARIOUS COUNTRIES 1-57 (2d ed. 1889) (describing the progress of the Australian ballot movement in Australia and as adopted in Europe, Canada, and the United States); see also L.E. FREDMAN, THE AUSTRALIAN BALLOT: THE STORY OF AN AMERICAN REFORM 10 (1968) ("IIt] virtually terminated bribery, lavish treating, and disorder at elections.").

11. An opponent of mandated anonymity could coherently advance both objections by arguing that mandated anonymity will not stop corrupt donors from signaling candidates, but will deter noncomupt donors from donating.

12. See, e.g., Jac C. Heckelman, The Effect of the Secret Ballot on Voter Turnout Rates, 82 PUB. CHOICE 107, 119 (1995) (estimating a $6.9 \%$ drop in voting in states utilizing the secret ballot and attributing said drop to the elimination of bribery); see also GEOFFREY BRENNAN \& LOREN LOMASKY, DEMOCRACY AND DECISION: THE PURE THEORY OF ELECTORAL PREFERENCE 219-20 (1993) ("Arguably, some of the point went out of voting once voting ceased to involve an open declaration of one's political convictions."); John R. Lott, Jr. \& Larry Kenny, How Dramatically Did Women's Suffrage Change the Size and Scope of Government? tbl.2 (unpublished manuscript, on file with the Stanford Law Review) (noting that the secret ballot reduced voter turnout by $2 \%$ to $4 \%$ ). 
But facilitating influence peddling is too high a price to pay to finance larger campaigns. And reducing six-figure donations will increase the relative importance of two and three-figure donors and possibly their willingness to give. ${ }^{13}$

While mandated anonymity might be combined with a variety of proposals for campaign finance reform-including Bruce Ackerman's innovative "Patriot dollar" proposal14 - the donation booth is narrowly tailored to respond to the government's compelling interest in deterring political corruption and is therefore more likely than other reforms to pass constitutional muster. Just as there is no constitutional right to prove you voted for Clinton, there is no constitutional right to prove you gave Clinton money. The current contribution caps indirectly discourage political corruption by limiting the maximum "price" of influence. We suggest, instead, that it may be more effective to create uncertainty about whether the price was ever paid.

This article is divided into three parts. Part I shows how donor anonymity might disrupt the market for political influence. Part II then describes in more detail how a system of mandated anonymity might operate and how donors and candidates are likely to respond. To avoid the "nirvana fallacy" of comparing an idealized reform proposal to a real-world market failure, we assess whether the private efforts to evade anonymity or recharacterize contributions as protected speech-via "independent expenditures" or "issue advocacy"- undermine the usefulness of our proposal. We will weigh the "benefits" of eliminating political action committee ("PAC") bundling and sharply reducing soft money against the costs of less information for voters and donors to PACs (and other political intermediaries).

Part III assesses the constitutional and political feasibility of mandating donor anonymity. Although we conclude that this reform is clearly constitutional, we are less sanguine about its chances for passage. After all, any reform trying to divest vested interests will face an uphill battle.

\section{Mitigating THE PROBLEMS OF POLITICAL CORRUPTION}

The corrupting influence of campaign contributions has been a central concern of finance reform. ${ }^{15}$ The notion that wealthy donors are able to pur-

13. A more serious concern is that reducing the influence of large donors may also increase the relative influence of other dominant speakers, especially the media. See text accompanying notes 146-147 infra.

14. See generally Ackerman, supra note 3. The relative merits of Patriot dollars and donation booths are discussed later in this article. See text accompanying notes 158-176 infra.

15. See Cass R. Sunstein, Political Equality and Unintended Consequences, 94 CoLUM. L. REV. 1390, 1391 (1994) (identifying corruption as the "[f]irst and most obvious, perhaps," ground for campaign finance reforms). The other core goal has been a commitment to reducing inequality. See J. Skelly Wright, Money and the Pollution of Politics: Is the First Amendment an Obstacle to 
chase political access or influence is antithetical to our ideal of equal citizenship. ${ }^{16}$ As Cass Sunstein has observed, "[T]here is no good reason to allow disparities in wealth to be translated into disparities in political power. A well-functioning democracy distinguishes between market processes of purchase and sale on the one hand and political processes of voting and reasongiving on the other."17 Bruce Ackerman also advocates separating market and political processes: "A democratic market society must confront"a basic tension between its ideal of equal citizenship and the reality of market inequality. It does so by drawing a line, marking a political sphere within which the power relationships of the market are kept under democratic control."18 The most popular reforms for decoupling these spheres operate by regulating money: They either limit the amount that donors can give, or they limit the amount that candidates can spend.

But there is another way to decouple private wealth from public power. Instead of limiting money, we might limit information. Since Watergate, the only informational reforms have been those that have increased the amount of mandated disclosure. Today, the impulse for further disclosure continues unabated with proposals for instantaneous disclosure of contributions on the Internet. Discussions of disclosure often assume that we must choose between a world in which everyone knows of a gift (the disclosure regime) and a world in which only a donor and her candidate know the source of a gift (the laissez-faire regime). But as shown in Table $\mathrm{I}$, this analysis overlooks the possibility of moving toward a world in which only the donor knows about a gift.

TABLE I

\begin{tabular}{|l|l|}
\hline \multicolumn{2}{|c|}{ Three Different Informational Regimes } \\
\hline Disclosure Regime & Donor, Candidate, and Public Know \\
\hline Laissez-Faire Regime & Donor and Candidate Know \\
\hline Mandated Anonymity Regime & Only Donor Knows \\
\hline
\end{tabular}

Political Equality?, 82 COLUM. L. REV. 609, 625-26 (1982). And at least one article has suggested that reform should further no fewer than five goals: competition, accountability, fairness, responsibility, and deliberation. See David Donnelly, Janice Fine \& Ellen S. Miller, Going Public, BOSTON REV., Apr.-May 1997, at 3. The concept of corruption itself has taken on several different meanings. See Thomas F. Burke, The Concept of Corruption in Campaign Finance Law, 14 CoNST. COMMENTARY 127, 128 (1997) ("Even the dictionary definitions of corruption suggest that it is a tricky term.").

16. See Daniel Hays Lowenstein, On Campaign Finance Reform: The Root of All Evil Is Deeply Rooted, 18 HoFSTRA L. REV. 301, 302 (1989) ("IP]ayment of money to bias the judgment or sway the loyalty of persons holding positions of public trust is a practice whose condemnation is deeply rooted in our most ancient heritage.").

17. Sunstein, supra note 15 , at 1390 .

18. Ackerman, supra note 3 , at 71 . 
The impetus for disclosure is that a public armed with knowledge about political contributions will be able to punish candidates who sell their office or who are otherwise inappropriately influenced. ${ }^{19}$ However, it has proved exceedingly difficult to infer inappropriate influence from the mere fact of contributions. Politicians claim they would have acted the same way regardless of whether a questionable contribution had been made..$^{20}$

Moreover, we have been unwilling to prohibit selling access in return for contributions. The Attorney General has flatly concluded that such quid pro quo agreements are legal. ${ }^{21}$ And today's jaded citizenry imposes hardly any electoral punishment on candidates known to have sold political access. In sum, public disclosure produces very little deterrent benefit: Types of corruption that can be proved (contributions for access) are legal, and types of corruption that are illegal (contributions for influence) can't be proved. At most, disclosure deters only the most egregious and express types of influence peddling. In contrast, a regime of mandated anonymity interferes with an informational prerequisite for corruption. Put simply, it will be more difficult for candidates to sell access or influence if they are unsure whether a donor has paid the price. Of course, much turns on whether government can actually keep candidates uninformed about who donates to their campaigns. But to begin, we consider what an idealized regime of mandated anonymity-without evasions or substitute speech-can and cannot accomplish.

Disproportionate wealth can be translated into disproportionate political power in three important ways:

(1) Quid Pro Quo Corruption: Wealthy contributors might implicitly or explicitly trade donations for political access or influence.

(2) Monetary Influence Corruption: Even without implicit deals, politicians might choose their positions so as to increase their contributions.

19. In Buckley v. Valeo, 424 U.S. 1 (1976) (per curiam), the Supreme Court explicitly grounded the government interest in this theory:

[D]isclosure requirements deter actual corruption and avoid the appearance of corruption by exposing large contributions and expenditures to the light of publicity. This exposure may discourage those who would use money for improper purposes either before or after the election. A public armed with information about a candidate's most generous supporters is better able to detect any post-election special favors that may be given in return.

Id. at 67 (citations omitted).

20. See note 6 supra and accompanying text.

21. According to Attomey General Janet Reno:

The courts that have addressed the issue have held that such access in exchange for political contributions is not an "official act" that can provide the basis for a bribery or extortion prosecution. See United States v. Carpenter, 961 F.2d 824,827 (Ninth Circuit, 1992) ("granting or denying access to lobbyists based upon levels of campaign contributions is not an 'official act'")....

Like the bribery and extortion statutes, [18 U.S.C. $\S 600]$ does not apply to providing access in exchange for political contributions....

Letter from Janet Reno, United States Attorney General, to Rep. Henry J. Hyde, House Judiciary Chairman, reprinted in N.Y. TIMES, Oct. 4, 1997, at A9. 
(3) Inequality: Even if candidates' behavior were wholly independent of potential donations (candidates uncorrupted by donations), the ability of wealthy contributors to fund candidates of their liking might increase the chance that those candidates will win. ${ }^{22}$

These are the core problems of implementing equal citizenship in a world with unequal resources. Mandated anonymity might mitigate each of these problems.

\section{A. Quid Pro Quo Corruption}

As suggested above, an idealized donation booth would severely impede quid pro quo corruption. This effect would encompass not only explicit trades (donations for nights in the Lincoln bedroom, presidential coffees, legislative activity), ${ }^{23}$ but also a large range of implicit deals, including sequential action whereby either the politician or donor "performs" in expectation of subsequent performance by the other side. The Supreme Court's concern with the corrupting effects of "political debts"24 would also be neutralized by the donation booth for the simple reason that politicians would be unable to determine to whom they were indebted. This rationale was explicitly used to justify a proposed system of anonymous donations to presidential legal defense funds. In 1993, the Office of Government Ethics ("OGE") reasoned, "Anonymous private paymasters do not have an economic hold on an employee because the employee does not know who the paymasters are.

22. See Burke, supra note 15, at 131 (arguing that Supreme Court decisions have identified "three distinct standards of corruption," which the author labels "quid pro quo," "monetary influence," and "distortion"). Thomas Burke shows how each of these effects has been characterized as a problem of corruption, although the last possibility-"distortion"-is more often described as the problem of inequality. See id.

Disproportionate wealth, however, is not a prerequisite for either the quid pro quo or the monetary influence forms of corruption. Collectively, citizens of relatively modest means might collectively amass sufficient resources to influence candidate behavior corruptly.

23. See generally Jane Mayer, Inside the Money Machine: How the Democrats Went Wild, NEW YORKER, Feb. 3, 1997, at 32 (detailing political fundraising excesses over the last 30 years).

24. In First National Bank of Boston v. Bellotti, 435 U.S. 765 (1978), the Court distinguished the Massachusetts law under review from the longstanding Federal Corrupt Practices Act, which bars corporate spending in candidate elections. The Court stated, "The overriding concern behind the enactment of statutes such as the Federal Corrupt Practices Act was the problem of corruption of elected representatives through the creation of political debts. The importance of the governmental interest in preventing this occurrence has never been doubted." Id. at 788 n.26 (citation omitted). In discussing this opinion, Thomas Burke noted:

Here again the Court seems to go beyond the concern about quid pro quo vote-trading, this time to characterize corruption as "the creation of political debts." Four years later, in FEC v. National Right to Work Comm., the Court again discussed the need to insure that corporate "war chests" not be used to create "political debts."

Burke, supra note 15, at 132 (quoting Bellotti, 435 U.S. at 788 n.26, and FEC v. National Right to Work Comm., 459 U.S. 197, 207 (1982), respectively). 
Moreover, the employee has no way to favor the outside anonymous donors."25

Mandated anonymity could also deter politicians from extorting donations. The popular discussion of quid pro quo corruption focuses solely on campaign contributions in return for legislative favors. In the terminology of public choice theory, donors would be engaged in a kind of "rent seeking." But there is a radically different kind of quid pro quo corruption. ${ }^{26}$ Politicians engage in "rent extraction" when they threaten potential donors with unfavorable treatment unless a sufficiently large contribution is made. ${ }^{27}$

Rent extraction almost surely explains some of the anomalous patterns of giving-particularly, the "everybody loves a winner" phenomenon. The high level of contributions made to incumbents with safe seats is consistent with rent extraction because incumbents have the greatest ability to extort donations. ${ }^{28}$ Understanding rent extraction also explains why several corporations have privately agreed not to make soft money contributions. ${ }^{29}$

In analyzing the impact of rent extraction on campaign finance reform, David Strauss has explicitly drawn the comparison to vote extortion: "Although some such extortion might be possible if the currency were votes,

25. Op. Off. Gov't Ethics $93 \times 21$, at 93 (1993). See generally Kathleen Clark, Paying the Price for Heightened Ethics Scrutiny: Legal Defense Funds and Other Ways That Government Officials Pay Their Lawyers, 50 STAN. L. REV. 65 (1997). President Clinton initially considered requiring that donors be anonymous. See Office of Government Ethics Authorization Act of 1994: Hearings on H.R. 2289 Before the Subcomm. on Admin. Law and Governmental Relations of the House Comm. on the Judiciary, 103d Cong. 21 (1984) (statement of Michael H. Cardozo, Executive Director, Presidential Legal Defense Trust). In the end, the White House decided (with OGE approval) to require that all donors be identified because it feared that anonymity could not be maintained. See Letter from Michael H. Cardozo, Executive Director, Presidential Legal Defense Trust, to Stephen D. Potts, Director, OGE (July 20, 1994) (on file with the Stanford Law Review).

26. For a discussion of the subtle differences between bribery and extortion, see generally Ian Ayres, The Twin Faces of Judicial Corruption: Extortion and Bribery, 74 DENV. L. REV. 1231 (1997); James Lindgren, The Elusive Distinction Between Bribery and Extortion: From the Common Law to the Hobbs Act, 35 UCLA L. REV. 815 (1988); and James Lindgren, The Theory, History, and Practice of the Bribery-Extortion Distinction, 141 U. PA. L. REv. 1695 (1993).

27. See Fred S. McChesney, Rent Extraction and Rent Creation in the Economic Theory of Regulation, 16 J. LEGAL STUD. 101, 102 (1987) (arguing that politicians are not "mere brokers redistributing wealth in response to competing private demands, but independent actors making their own demands to which private actors respond"). Professor McChesney identifies particular situations in which private actors will be susceptible to threats by politicians to use regulation to lower prices or increase production costs. See id. at 112-17.

28. See FRANK J. SORAUF, INSIDE CAMPAIGN FNANCE: MYTHS AND REALITIES 60-97 (1992) (discussing the link between reelection rates and campaign finance); David A. Strauss, Corruption, Equality and Campaign Finance Reform, 94 Colum. L. REv. 1369, 1380 (1994) ("Some of the data-notably the high levels of contributions to incumbents with safe seats-suggests that [extortion of contributions] is quite common."); $c f$. Jamin Raskin \& John Bonifaz, The Constitutional Imperative and Practical Superiority of Democratically Financed Elections, 94 COLUM. L. REV. $1160,1176-77$ (1994) (detailing congressional incumbent's fundraising advantages).

29. See Richard J. Mahoney, Letter to the Editor, A Corporate Mood, N.Y. TMmS, Jan. 30, 1997 , at A14. 
instead of campaign contribution dollars, votes are cast in secret and can go only to one side; the dangers of extortion are therefore far greater when contributions are allowed." 30 Bruce Ackerman has similarly noted that voting secrecy has been crucial in deterring vote extortion: "Even if you refused a bribe, you were subject to retaliation from your employer or other rich folk. Only with the rise of the secret ballot, in the late nineteenth century, did Americans begin to build a political sphere that was insulated from the inequalities of the market."'31

But neither of these authors has seen that donation secrecy can play a similar role in deterring donation extortion. Fred McChesney has persuasively argued that fear of rent extraction may even keep private interest groups from organizing because politicians will have a harder time shaking down an unorganized mass. ${ }^{32}$ Mandated donor anonymity would allow private interests to organize without fear of being targeted for extortion.

Just as the secret ballot substantially deterred vote buying, mandating secret donations might substantially deter both forms of quid pro quo corruption: rent seeking and rent extraction. There is a lively academic debate about how much campaign funding is intended to garner access or influence or to avoid unfavorable treatment. ${ }^{33}$ Since the donation booth is particularly tailored to deter quid pro quo corruption, an important part of its justification must turn on the extent to which this form of corruption is truly a problem. However, as discussed above, the problems of "monetary influence corruption" or "inequality" also plague our current system of campaign finance. Although mandated anonymity would not eliminate these problems, the next section will show that a donation booth is likely to mitigate them.

\section{B. Monetary Influence and Inequality}

Even when politicians don't condition their behavior on contributions, they may nonetheless expect that taking certain positions will cause donors to give more money. And even when wealthy donors don't expect their giving to change a candidate's behavior, they may reasonably believe that giving to a candidate with whom they agree will increase that candidate's chance of (re)election. We have characterized these two phenomena as the problems of monetary influence and inequality. In the first instance, the pos-

30. Strauss, supra note 28 , at 1380 (emphasis added).

31. Ackerman, supra note 3, at 71 .

32. See Fred S. McChesney, Rent Extraction and Interest-Group Organization in a Coasean Model of Regulation, 20 J. LEGAL STUD. 73, 85-89 (1991) (arguing that a "well-organized group represents more aggregated amounts of transferable/extractible surplus [for politicians] than do disaggregated individuals").

33. See generally Stephen G. Bronars \& John R. Lott, Jr., Do Campaign Donations Alter How a Politician Votes? Or, Do Donors Support Candidates Who Value the Same Things That They Do?, 40 J.L. \& ECON. 317 (1997). 
sibility of a contribution has a corruptive influence on the candidate's behavior. In the second, even though the candidate's positions are uncorrupted (read "unchanged") by the contribution, the contributions of those with disproportionate wealth corrupt the process by increasing the likelihood that positions favored by the wealthy will be disproportionately favored in our political sphere. ${ }^{34}$

Some might argue, however, that monetary influence is not a problem because donors' willingness to pay usefully informs candidates about the intensity of voter preferences. 35 Yet there is strong consensus from a broad range of scholars that politicians should not choose their policies with an eye toward campaign contributions. ${ }^{36}$ Not all interest groups can readily organize to compete for candidates' monetary interests. A concentrated interest group advocating a law that decreases social welfare may still be able to donate more money than can more diffuse interests opposing the measure. Under such conditions, donations may give candidates a false signal of citizens' intensity of preference. Insulating candidates from the influence of donations may lead toward legislation that more truly reflects the preference intensity of voters. ${ }^{37}$ Monetary influence corruption, like vote buying, is re-

34. Sandy Levinson has noted that disparate wealth would not be a major concern if political views were randomly distributed across class. As an empirical matter, the problem is that the relatively rich tend to prefer laws different from those preferred by the relatively poor. See Sanford Levinson, Regulating Campaign Activity: The New Road to Contradiction?, 83 MrCH. L. REV. 939, 945 (1985).

35. See, e.g., Strauss, supra note 28, at 1374 ("[C]ontributions allow voters-that is, contributors-to register the intensity of their views."); Sunstein, supra note 15, at 1393 ("[W]e might take the ability to attract a large amount of money to reveal something important-if not decisive-in a deliberative democracy."). But see Edward B. Foley, Equal-Dollars-Per-Voter: A Constitutional Principle of Campaign Finance, 94 CoLuM. L. REV. 1204, 1204 (1994) (arguing that, given disparities in wealth, there is only a weak correlation between a contributor's willingness to give and her intensity of preference).

Strauss argues that, in a world without inequality, "comuption" is not so bad: "[B]ribes' ... are like vouchers redeemable only for a certain purpose." Strauss, supra note 28 , at 1372 . Strauss adds, "If equality is secured, then because campaign contributions are valuable only as a means to get votes, rewarding a legislator with a contribution is, in important ways, similar to the unquestionably permissible practice of rewarding her with one's vote." Id. at 1373 . This assertion is problematic; it fails to recognize that explicit vote trading is not clearly permissible.

36. For example, even market-oriented scholars such as James Buchanan and Gordon Tullock have argued that contributions might not accurately measure intensity of preferences because of "market imperfections":

The individual, considering organizational rules, may well think that vote-marketing, if it could operate perfectly, would reduce expected external costs. However, he may also predict imperfections in this market which may more than offset this advantage. With expected market imperfections of a certain type, the individual may choose rationally to try to prohibit the open buying and selling of political votes.

James M. BuchanaN \& GORDON TUlLOCK, The CALCUlus OF CONSENT: Logical FOUNDATIONS OF CONSTITUTIONAL DEMOCRACY 272 (1962).

37. The possibility of rent extraction also militates against using donations to register the preference intensity of voters. Politicians trying to extort donations under threat of harmful laws are likely to pass a retaliatory law from time to time in order to make their threats credible. An 
jected because the legitimate preferences of citizens with unequal abilities to pay or unequal opportunities to pay are given undue influence. ${ }^{38}$ Moreover, citizens can credibly signal the intensity of their preferences by engaging in other activities, such as marching on Washington, that are more generally available to a large proportion of the populace. Even if citizens wish to signal the intensity of their preferences by spending money, it is not clear that donating money is superior, literally, to burning the money for a cause. It is one thing for a candidate to change positions because her constituents are willing to part with considerable money. Such behavior is consistent with the idea that politicians should faithfully represent the aggregate preferences of their constituents. But it is another thing to change positions in order to receive this money. Because there is no natural way to aggregate preferences, it is suspect for a candidate to choose an aggregation that selfinterestedly increases her chance of election.

Scholars have also rejected the notion that contributions should influence politicians in part because contributions tend to reduce independent deliberation and reason-giving. ${ }^{39}$ David Strauss, in particular, has argued:

[O]n any plausible conception of representative government, elected representatives sometimes should exercise independent judgment .... Campaign contributions do not create the possibility that representatives will follow instead of lead; that is an unavoidable (and to some extent desirable) part of any democracy. But because contribution-votes can be so much better targeted than votes at the ballot box, a system in which contributions are explicitly exchanged for official action will accentuate this tendency of representative government. ${ }^{40}$

Under this view, the monetary influence of contributions impedes the deliberative processes of democracy. At times, representatives should take positions that are not merely aggregations of their constituents' preferences.

Mandated anonymity would reduce the corrupting influence of contributions on candidates' behavior by reducing both the candidates' feedback about how particular positions affect giving and the willingness of donors to make large donations to influence candidate behavior. Candidates would still learn (from time to time ${ }^{41}$ ) the total amount of money that had been contributed to their campaigns, but they wouldn't learn how particular positions

uninsulated system of monetary influence might therefore lead to worse policies than one that insulates candidates from the preference intensity of voters.

38. See generally Daniel R. Ortiz, The Democratic Paradox of Campaign Finance Reform, 50 STAN. L. REV. 893 (1998) (explaining why vote buying is bad).

39. See Burke, supra note 15 , at 148 ("[W]here contributor-influenced representatives predominate, legislative deliberation becomes a sham.").

40. Strauss, supra note 28 , at $1375-76$.

41. See text accompanying notes 67-68 infra (discussing the frequency of disclosures). 
translate into particular contributions. ${ }^{42}$ Mandated anonymity would create a kind of Tiebout model ${ }^{43}$ for candidates' policies. In the original Tiebout model, different towns committed to particular taxes and amenities, and then potential citizens voted with their feet by moving to the towns with the tax and expenditure package they most preferred. ${ }^{44}$ Mandated anonymity would push the contribution market in the same direction. Politicians would announce policies and wait and see whether those policies garnered financial support. This might not be the true independent leadership Strauss might ideally want, but it is likely to be more independent than the current regime-one in which private interests can bestow gifts on a politician in full expectation that she will see and appreciate on which side her bread is buttered. ${ }^{45}$

Past giving would be a poor guide for predicting future donations under a mandated anonymity regime because donor anonymity would exacerbate the "donor's paradox." 46 Just as it is irrational to vote when there is an infinitesimal chance that one's vote will affect the election, it is irrational to give if one's gift imperceptibly increases the chance of a candidate's victory. Under the current regime, politicians overcome the donor's paradox by developing a reputation for giving donors special consideration; large donors expect their contributions to yield concrete benefits concerning a candidate's policy, legislative activity, or at the very least, the candidate's willingness to meet with the donor. But mandated anonymity greatly diminishes the expected return on an individual donation and thus, in all likelihood, will substantially reduce the number of large donations. ${ }^{47}$ It would be difficult for candidates

42. As we will make clear below, we favor letting donors talk about donations, but because such representations would not be credible, it would be impossible for politicians to know whether the representations were true. See text accompanying notes 68-72 infra.

43. See generally Charles M. Tiebout, A Pure Theory of Local Expenditures, 64 J. POL. ECON. 416 (1956).

44. See id. at 418.

45. Richard Craswell has suggested to us that it might be possible to use a modified version of the donation booth to give candidates information about voters' aggregate preferences, but not voters' identities. See Interview with Richard Craswell, Professor of Law, University of Chicago Law School, in Chicago, Ill. (Jan. 13, 1998). If the blind trusts solicited donors' policy preferences and revealed these preferences to the candidates-for example, if the trusts revealed that $\$ 300,000$ of total donations support NAFTA - the mandated anonymity regime might reveal something more to the candidates about the intensity of the donors' aggregate preferences while still disrupting the market for quid pro quo corruption.

46. See Strauss, supra note 28 , at 1383-84 ("People's willingness to make relatively small contributions, even though the likely effect on the outcome is minimal, is parallel to the 'voter's paradox'-their willingness to vote even though the likely effect of their single vote is also minimal."). On the voter's paradox generally, see ANTHONY DOWNS, AN ECONOMIC THEORY OF DEMOCRACY 206-76 (1957); Dennis C. Mueller, Voting Paradox, in DEMOCRACY AND PUBLIC CHOICE 77 (Charles K. Rowley ed., 1987).

47. We return to this crucial prediction in Part II.C in considering real world problems of implementation. 
to provide favors or special access for individual contributors without knowing the contributors' identities.

Mandating donor anonymity would reduce the disproportionate influence of wealth in our political system not only by reducing the number of large donations, but also by increasing the number of small donations. While mandating anonymity exacerbates the donor's paradox for large donors, the same anonymity might mildly mitigate the paradox for small donors. Under the current system, small donors have virtually no impact on the electoral process. "For example in the 1996 election cycle less than one-fourth of 1 percent of the American people gave contributions of $\$ 200$ or more to a federal candidate," 48 but this tiny group of donors generated an astonishing eighty percent of total donations. ${ }^{49}$ By reducing the importance of large donations, mandated anonymity would make small donors relatively more important and thus might induce less affluent donors to give more. ${ }^{50}$

Mandated anonymity, if achievable, is well-suited to deter quid pro quo corruption. But the donation booth is not a panacea. Candidates would still have some incentive to take certain positions in order to generate contributions, ${ }^{51}$ and the wealthy would continue to have a disproportionate voice in electioneering. But by (1) making it harder for politicians to reward their contributors, (2) substantially reducing the number of large donors, and (3) possibly increasing the number of small donors, a regime of mandated anonymity could mitigate the problems of monetary influence and inequality.

A reform of mandated anonymity would by itself probably lead to an overall reduction in giving. Some will argue that reduced giving is a severe defect because campaign speech is already underfunded.52 But facilitating corruption and influence peddling is too high a price to pay for funding larger campaigns. At the end of the day, we might want to combine mandated anonymity with something akin to the Patriot dollar or "Clean Money" plans of public finance..$^{53}$ But as we will see, ${ }^{54}$ mandated anonymity would

48. Donnelly et al., supra note 15 , at 3 .

49. See id.

50. To be sure, highly rational, small donors will still face a donation paradox. But as with the voting paradox, civic-minded citizens might overcome their narrow self-interest and, from the standpoint of rational choice theory, donate in surprising numbers.

51. For example, politicians rationally might expect a candidate's antigun control position to produce contributions from the National Rifle Association.

52. One might argue that we are currently spending too much on campaign speech-or at least that we are getting too little useful discussion for the amount that we are spending.

53. See Ackerman, supra note 3 , at 76 (describing the Patriot voucher plan, a plan by which candidates are granted public money in proportion to their popularity); Donnelly et al., supra note 15, at 6-7 (describing the Clean Money plan as involving a shortened election season and prohibiting candidates from accepting any private money after accepting public funds).

54. See text accompanying notes 158-176 infra (discussing how mandated anonymity might be combined with these plans). 
continue to be necessary to reduce the corrupting effects of contributions under even the most ambitious public finance plans. And if the Supreme Court mandates a continuing role for private contributions, then even under a restrictive public finance plan, mandated anonymity would play an important role in decoupling the economic and political spheres.

\section{CONFRONTING PRACTICAL PROBLEMS OF IMPLEMENTATION}

The preceding part considered the effects of an idealized system of mandated anonymity. But to avoid the nirvana fallacy, 55 we must consider whether and how anonymity could be implemented. If candidates could easily decode the identity of their contributors, then the superficial requirement of anonymity would be counterproductive: We would lose the limited benefits of public disclosure and gain nothing, thus permitting quid pro quo corruption to proceed unabated. ${ }^{56}$ This part considers the details of implementation, assesses the extent to which anonymity can be maintained, and ultimately concludes that, even given predictable evasions, mandating donor anonymity could be a useful reform by itself or in combination with other pending reform measures.

\section{A. Details of Implementation}

Mandated donor anonymity might be applied to any election. As we will see, some judicial election reforms have already successfully prevented candidates from learning the identity of their donors. ${ }^{57}$ For concreteness, we consider how to implement a regime of mandated donor anonymity in federal elections.

\section{Private versus public administration.}

One could imagine a system of literal donation booths controlled by the government: Once the curtain closed, people could drop their cash donations into a slot for the candidate of their choice, and the government would periodically pass these contributions on to the appropriate candidates. Just as there is a "ceremonial aspect[] of voting ... [that] is to some degree a self-

55. See Richard L. Hasen, Clipping Coupons for Democracy: An Egalitarian/Public Choice Defense of Campaign Finance Vouchers, 84 CALIF. L. REV. 1, 17 (1996) ("We should be wary of committing the "nirvana fallacy' of comparing real-world institutions to an 'ideal institution [that] has never existed or . . . has been proven impossible to devise."' (quoting Maxwell L. Stearns, The Misguided Renaissance of Social Choice, 103 YALE L.J. 1219, 1229-30 (1994))).

56. See note 19 supra and accompanying text (discussing the deterrence benefits of public disclosure). tions).

57. See text accompanying notes 119-142 infra (describing donor anonymity in judicial elec- 
conscious act of citizenship," 58 visiting a government donation booth might in time also come to be viewed as a constitutive act of citizenship.

Donation booths-whether publicly or privately administered-run greater risks of fraud than do voting booths. For either "booth" to be effective, we must trust the administrator not (1) to reveal for whom citizens vote or to whom they donate, or (2) to misapply the donation or vote to an unintended candidate. But with donations-unlike votes-there is the added risk that the administrator will convert the gift to her own private benefit.

Because of this embezzlement risk, we tentatively prefer a privatized system of blind trusts, ${ }^{59}$ operated by seasoned trust companies (say, those in existence for at least ten years) with substantial, preexisting assets (of more than, say, $\$ 100,000,000){ }^{60}$ More than 1000 financial institutions satisfy these requirements. ${ }^{61}$ Requiring the trust companies to be seasoned and large would make donors, candidates, and the public more likely to trust the participating institutions. The diversity of qualifying institutions would help assure that all candidates are treated fairly. But because the threat of defalcation is so high, we also favor publicly auditing the trusts' records ten years after each election. This ex post auditing would inform donors whether their donations had been properly routed and would allow the public to assess whether donations were-notwithstanding the trust-purchasing access or influence. In the near future, computer encryption software might make it possible for donors to verify anonymously that their contributions were credited to the appropriate campaign funds. ${ }^{62}$

58. Strauss, supra note 28 , at $1376 \mathrm{n} .18$.

59. Courts have prohibited political parties from creating perpetual trusts. See 4A AUSTIN WAKEMAN SCOTT \& WILLIAM FRANKLIN FRATCHER, THE LAW OF TRUSTS $§ 374.6$ (4th ed. 1989) ("It is against public policy to permit the perpetual endowment of a political party."); John D. Perovich, Annotation, Validity and Construction of Testamentary Gift to Political Party, 41 A.L.R.3d 833, $836 \mathrm{n} .9$ (1972) (discussing case law to the effect that "a political party ... does not come within the category of a charitable institution"). But a blind trust established for the limited duration needed to fund a political campaign would not run afoul of common law or statutory trust norms.

60. Similar requirements have been imposed on trusts serving as corporate fiduciaries. See CAL. FIN. CODE $\S \S 1500-1591$ (West 1989) (imposing requirements such as security deposits on trust companies); John H. Langbein, The Contractarian Basis of the Law of Trusts, 105 YALE L.J. $625,638-39 \&$ n.64 (1995) (describing modern-day, institutional trusteeships).

61. See Federal Deposit Insurance Corporation, Summary of Deposits (visited Sept. 18, 1997) <http://192.147.69.47/sod96/tbll.html> (tabulating financial institution deposit size).

62. Jack Balkin, Larry Lessig, and Silvio Micali have advised us that it would be possible to set up a system of digital signatures that allows a donor to trace the flow of her contribution through a blind trust to the account of a particular campaign, but would not allow the campaign to determine the identity of the donor. Any technology that gives donors the ability to verify that a contribution was deposited might also allow donors to show the authenticating screen to candidates to prove they have given. This is similar to the "canceled check" problem discussed at text accompanying note 70 infra. Such problems can be mitigated by giving faux donors the option of having authenticated contributions returned to them by means of a separate check from the blind trust. 


\section{Mechanics of blind trust operation.}

Under our proposal, each candidate, political party, and PAC would establish a blind trust account at a qualified institution.63 Representatives of the blind trust could not be employed in positions influencing access or policy and, as a prophylactic, should be prohibited from privately communicating with candidates or campaign workers. The core regulation would require all donations to individual candidates, political parties, or PACs to be made to the blind trusts by mail. Campaigns would no longer be allowed to accept money in cash or by check. Campaigns would still need check books, but not deposit slips. The blind trusts would conceal the source of all contributions larger than $\$ 200$. Large donors would have the option of having the trust disclose that they had given up to $\$ 200,{ }^{64}$ but under no circumstance would the trust identify a donor as having contributed more than $\$ 200.65 \mathrm{We}$ have no particular stake in the exact dollar amount for the anonymity threshold, ${ }^{66}$ but our notion is that small donations pose a much smaller threat of

63. There would be a single trust account for each candidate. We envision that each candidate be given the choice of which qualified trust company to use. If unfettered candidate choice creates too large a possibility that the trust will leak the donors' identities, it might instead be possible for the Federal Election Commission ("FEC") to give each candidate a random list of five or ten qualified trust companies from which to establish an account.

64. As discussed below, we would give all donors the option of absolute anonymity. See text accompanying notes 151-153 infra (explaining our preference for optional partial disclosure rather than mandated partial disclosure).

65. For concreteness, we propose combining our regime of mandated anonymity with the current contribution limits. However, our proposal might easily be combined with proposals that either increase or decrease those limits.

In Buckley, the Supreme Court grounded mandatory disclosure requirements in part on the need to enforce contribution limits: "Third, and not least significant, recordkeeping, reporting, and disclosure requirements are an essential means of gathering the data necessary to detect violations of the contribution limitations described above." Buckley v. Valeo, 424 U.S. 1, 67-68 (1976) (per curiam).

Under a regime of mandated anonymity, compliance with the contribution limits could be enforced in one of three ways: (1) the public audit 10 years after the election could be used to uncover and penalize violations; (2) representatives of the blind trustees could have a duty to audit contemporaneously the contributions for compliance and publicly report violations; or (3) the trust could privately turn over a list of contributions to the FEC for auditing. The federal system currently requires political committees to keep the names and addresses of those who contribute over $\$ 50$ so that the FEC may audit them privately. See 2 U.S.C. $\$ \S 432$ (c)(2), 438(b) (1994) (mandating recordkeeping by the treasurers of political committees and providing for audits of those records). We favor a combination of the first two approaches because the third approach increases the number of politically connected people-working for the FEC-who gain knowledge of the contributors' identities.

66. Buckley gave Congress wide latitude in setting monetary thresholds:

[T] here is little in the legislative history to indicate that Congress focused carefully on the appropriate level at which to require recording and disclosure. Rather, it seems merely to have adopted the thresholds existing in similar disclosure laws since 1910. But we cannot require Congress to establish that it has chosen the highest reasonable threshold. The line is necessarily a judgmental decision, best left in the context of this complex legislation to congressional 
corruption. At the same time, allowing donors to reveal to candidates that they have given up to $\$ 200$ mitigates the free speech burden of the regulation. ${ }^{67}$

The blind trusts would then report to the candidates on a weekly or biweekly basis how much money had been donated, but would not detail the amounts given by large donors. The frequency of reporting would have to balance the candidate's need to know how much she could spend against the desire to impede candidates from decoding the identity of particular donors. Hourly disclosure of amounts available would allow a donor to say, "I bet your total went up $\$ 100,000$ during the past hour." Large donations on Israel's independence day might analogously signal contributors' interest in pro-Israel policies. If donor anonymity were required in conjunction with current contribution limits, there would be little risk that federal candidates could decode the presence of particular gifts from the disclosure of weekly totals. "Soft money" donations to parties pose a larger problem because they are not subject to any contribution limits. One way to shorten the time between disclosures would be to require that trusts intentionally obscure the presence of large donations. Trusts might even be allowed to report the daily amount available for spending, but this amount might be calculated using a randomizing procedure that breaks up unusually large contributions for future disclosure.

\section{Donor speech.}

One might consider reinforcing the anonymity of the blind trust by prohibiting donors from discussing their contributions with the candidate or others. Such a prohibition could be backed up by criminal penalties, civil penalties, or both. But such a regulation is fraught with problems of enforcement and constitutionality. The law can do little to stop private, one-on-one conversations between donors and candidates. Even if we could regulate such conversations, the resulting burden on donors' free speech rights may not be compatible with the First Amendment.

We prefer a "cheap talk" regime. Just as anyone can tell Clinton they voted for him, we suggest allowing anyone to tell Clinton they gave him money. For the blind trusts to be effective, it is only necessary that donors cannot credibly communicate whether they have contributed. As long as the

discretion. We cannot say, on this bare record, that the limits designated are wholly without rationality.

Buckley, 424 U.S. at 83 (citation omitted). Under an alternative regulation with a zero-dollar threshold, the trust would never report the size of the donor's contribution, but would merely give the donor the option of indicating that she had given something.

67. It would of course be necessary to prohibit multiple small gifts. The contemporaneous and public ex post audits could look for such evasions. For a discussion of the free speech implications of the $\$ 200$ threshold, see text accompanying notes 177-194 infra. 
candidate cannot verify whether the donor's representation is true, the blind trust can impede influence peddling. Some will argue that it is simply wrong for the government to tacitly promote lying. We, however, would like to instill the idea that it can be a civic virtue to suborn social ambiguity in order to disrupt criminal activity. The possibly apocryphal World War II story of the Danish King wearing - and urging other Christians to wear-the Jewish yellow star is a prime example of the virtue of social "ambiguation."68 More prosaically, the ubiquitous (and oftentimes false) cab driver stickers-"Not more than $\$ 20$ kept by driver"--shows that lying to discourage crime is an acceptable exception to truth telling. ${ }^{69}$

Donors wishing to prove they donated to a particular candidate may brandish a canceled check showing the amount of their donation. To mitigate this problem, we suggest that trusts only accept checks made out generically to the trust company ("Payable to the Order of First Boston") without any indication of the candidate for whom the contribution is intended. An additional advantage of limiting intermediation to major financial institutions is that a $\$ 1000$ check payable to Citibank would not dispositively prove that a political donation had been made. ${ }^{70}$

We might want to further obfuscate evidence of contributions by requiring that blind trusts cash checks for both donors and nondonors. To eliminate the risk of insufficient funds, the trust would wait until the nondonor's check had cleared and then mail a separate check for the same amount from the trust to the nondonor. The faux donor requesting reimbursement would receive both a canceled check from her bank and a reimbursement check from the trust. A candidate seeing a canceled check made out to a blind trust couldn't be sure whether the canceled check evidences a contribution or merely a cash conversion. And since the trust's reimbursement check could be cashed or posted to a different account, showing the candidate a bank statement or audited books would not prove that a contribution had been made. ${ }^{71}$ As with cheap talk, appropriate regulation could undermine the credibility of canceled checks.

68. See Lawrence Lessig, The Regulation of Social Meaning, 62 U. CHI. L. REV. 943, 101011 \& n.225 (1995) (citing JEWISH MUSEUM, KINGS AND CITIZENS: THE HISTORY OF THE JEWS IN DENMARK 1622-1983 (Jorgen H. Barfod, Norman L. Kleebatt \& Vivian B. Mann, eds., 1983)). Professor Lessig calls this concept "ambiguation" and describes its utility. See id. at 1010-12. If the State of California is serious that race should not play a role in admission to state universitiesa policy we do not support-it might consider encouraging candidates to misstate their race on applications or at the very least remove any penalties for misstating one's race.

69. Cf. Jennifer Gerarda Brown \& Ian Ayres, Economic Rationales for Mediation, 80 VA. L. REV. 323, 356-71 (1994) (explaining that mediator prevarication can provoke settlement).

70. Since trust companies might administer the accounts of several (possibly competing) candidates, evidence of a contribution to a trust would not necessarily indicate which candidate had received a donation.

71. The audited books of corporations pose a more difficult problem-to the extent corporations are allowed to donate-because all reimbursements back to the corporation should be re- 
Donors wanting to signal their gift credibly might instead mail the check to the blind trust while in the presence of a campaign representative (or simpler yet, give the check to the campaign worker to mail to the trust on the donor's behalf). We favor prohibiting such behavior. Yet even here, a system of mandated anonymity does not need to rely solely on the deterrent effect of ex post penalties. It might be advisable to give donors a ten-day cooling-off period, during which they could cancel any donation. ${ }^{72}$ As long as a period exists in which donors can privately cancel their contributions, the credibility of previous signals will be attenuated. A cooling-off period would not only mitigate this "mailbox" problem, it would also give candidates more fundraising flexibility-a topic to which we now turn.

\section{Soliciting contributions.}

The fundamental requirement would be that, in fundraising, no one from the candidate's campaign could accept contributions; only representatives of the blind trust could accept checks (via the mail). ${ }^{73}$ Candidates could still ask individuals for support, but they could not close the deal. Bob Dole could still have fundraisers and limit invitations to rich, registered Republicans. But under our regime of mandated anonymity, the invitations could not be conditioned on a campaign contribution, and the dinner could not be priced above cost. $^{74}$ Instead, campaign workers could do no more than distribute postage-free envelopes addressed to the blind trust so that attendees could later mail in a contribution. Making it more difficult for candidates

flected on its books. However, there is no reason why the publicly disclosed financial statements produced by audits need to disclose political donations. As far as we know, audited financials do not currently certify political contributions because the size of such contributions are not material. A regime of mandated anonymity would need to prohibit auditors from publicly or privately certifying the existence of political donations - or better yet, we might want to change ethical codes to allow auditors to certify donations falsely.

72. Cooling-off periods have been mandated in commercial contexts in which overreaching by the seller might impair the buyer's voluntary consent to a purchase. See 16 C.F.R. $\$ 429.1$ (1997) (defining unfair and deceptive acts in the context of door-to-door sales).

73. It might be that the donor's paradox is so severe that candidates feel compelled to invoke high-pressure closing techniques. See text accompanying notes 46-47 supra (describing the donor's paradox). The people doing the closing, however, would need to be employed by the trust-and thus insulated from the candidate. We could imagine a campaign delegating all fundraising activities to representatives of the blind trust. Some judicial campaigns have attempted this kind of acoustic separation. See text accompanying notes 119-142 infra (describing mandated anonymity in judicial elections). We worry, however, that such a scheme would give those people with political connections access to donor information and thereby increase the likelihood that anonymity might be breached. In any event, the need for a "closer" would be diminished in a regime with a cooling-off period.

74. Alternatively, any profit from a campaign event would need to escheat to the government or a nonpolitical charity. 
(and their political opponents) to solicit funds personally from wealthy contributors might alleviate the current fundraising marathon. ${ }^{75}$

This scheme of mandated anonymity would go a long way toward eliminating the longstanding practice of rewarding successful fundraisers with ambassadorships. The representatives of the trust could not take jobs or even consult with the administration. A candidate might observe a fundraiser's inputs (how many New Hampshire coffees she hosted), but not her output (how many donations she generated).

\section{Drawing the line.}

In deciding what types of contributions to subject to the anonymity requirement, we will be obliged to distinguish close cases. But Bruce Ackerman has observed that line drawing is a necessary feature of any reform program trying to constrain the influence of money in the political sphere. ${ }^{76}$ To begin, we would join the long list of reformers who would not regulate inkind contributions of services by political volunteers because it would be impossible for a candidate not to know their identities. ${ }^{77}$ Thus, people could still volunteer in order to receive undeserved access or influence. ${ }^{78}$ There is also no practicable way to stop candidates from knowing how much they contribute to their own campaign. ${ }^{79}$ We would not regulate volunteer serv-

75. Under a regime of mandated anonymity, candidates are likely to spend less time fundraising because this activity would be less productive and because the candidate would need fewer funds to effectively compete with an opponent who faces similar constraints. There is the theoretical possibility-called an "income effect"-that if anonymity causes less giving generally, then candidates will respond by engaging in more fundraising. As an empirical matter, however, economists typically find that substitution effects dominate income effects-that is, when fundraising becomes more difficult, politicians are likely to spend less time on it (especially when their opponents' fundraising also becomes more difficult).

76. See Ackerman, supra note 3, at 75 ("Any effort to insulate campaign finance from the unmediated rule of money requires us to cut the world into (at least) two spheres.").

77. See id. at 76 (describing the Patriot dollar plan); Hasen, supra note 55, at 25 ("Under the voucher plan, the value of any services volunteered by an individual would not count as a prohibited campaign contribution or expenditure."); Strauss, supra note 28 , at 1384 (noting that the use of individuals' skills or celebrity "would, at least arguably, burden people's autonomy in a way that restricting the use of money does not").

Like other reform proposals, ours is underinclusive because it focuses solely on the corrupting effects of campaign contributions and not on interim forms of influence, such as lobbying.

78. Bruce Ackerman has tried to justify, on policy grounds, not regulating volunteers: "The point of a political campaign is to inspire lots of Americans to act as conscientious citizens . . . . Volunteers are not in it for the money." Ackerman, supra note 3, at 76. But see Foley, supra note 35 , at 1246 ("[C]itizens who donate money are often motivated by civic virtue, while citizens who donate time may hope to advance their careers and their own self-interest.").

79. But as the Supreme Court has noted, contributing to yourself does not present the same risks of quid pro quo or monetary influence corruption. See Buckley v. Valeo, 424 U.S. 1, 53 n.59 (1976) (per curiam) (contrasting contributions from one's immediate family with contributions from oneself). Self-contribution, however, often exacerbates problems of inequality. It has led Acker- 
ices and self-donation only because, pragmatically, we could not effectuate anonymity.

Benefit concerts present a difficult issue. If Barbra Streisand performs a series of concerts to benefit the Clinton campaign, Clinton could easily estimate how much revenue is being generated. Allowing benefit concerts would provide an easy end run of the rule mandating that fundraising dinners must be priced at cost. Many of today's $\$ 1000$-a-plate fundraising dinners could become tomorrow's $\$ 1000$-a-seat benefit concerts with only nominal entertainment. Accordingly, we would prohibit an individual or business from dedicating the proceeds from an event to a political campaign. The performer or audience could independently contribute; they just couldn't publicly promise that attendance ensures contribution. We would still allow politically motivated concerts and rallies, but any profit would need to escheat to the state (or possibly to a nonpolitical charity).

\section{B. Can Anonymity Be Maintained?}

Our metaprinciple of implementation is to allow nondonors to ape easily any signal that true donors might try to send. If nondonors can mimic the signals of donors, then donors will have difficulty credibly communicating their contributions. This principle explains our regulation of donor speech, check cashing, and cooling-off periods. Instead of prohibiting donors from speaking, we have opted for encouraging nondonors to use the same words. To undermine the credibility of a donor's canceled check, we would give nondonors the option of acquiring an identical canceled check by merely cashing a check with the blind trust. And to undermine the credibility of mailing a check in the presence of a campaign worker, we have suggested a cooling-off period so that nondonors can publicly donate and then privately cancel.

There are, however, limitations to our aping principle.80 A poor person can not credibly mimic the representations of a rich person-saying that she donated $\$ 10,000$, for example. But it is unlikely that ability to pay is a close enough proxy for willingness to pay to cause politicians to kowtow to rich people generally. For example, if a law mandated that sellers of Cadillacs could not learn the identity of their customers, we doubt whether sellers would respond by giving Cadillacs to the universe of rich people. Even if wealth (ability to pay) signals something about whether a donor actually

man to suggest prohibiting self-financed elections. See Ackerman, supra note 3, at 76 ("Perot should not be permitted to throw his green money around to buy the presidency.").

80. See notes 69 \& 72 supra and accompanying texts (describing the aping principle). Our aping principle also explains those types of contributions that our proposal cannot regulate. Nondonors cannot mimic physically volunteering for a campaign or giving to oneself, which we accordingly leave unregulated. 
gave, the important point is that the signal would be much weaker than it is now. Similarly, it would not be credible for liberals to represent that they contributed to conservatives (or vice versa). In the shadow of a donation booth, Ralph Nader could not credibly represent that he had donated to the Republican Party. At the end of the day, rich conservatives are the only people who would potentially make large soft money contributions to the Republicans. Therefore, it is reasonable to ask who among this group would be willing to go to the trouble of becoming a faux donor-to noise up the system, for example, by making the ratio of canceled checks to net donations fairly high. Our answer is that the current class of Republican contributors who either feel they are being extorted or think they are paying for favors are prime candidates to fake donation. Victims of extortion are likely to have few qualms about lying to avoid the political shakedown, and even those contributors who are trying to corrupt the system by buying political favoritism may prefer to get the same favoritism for a reduced price.

Although our proposal tries to undermine a donor's ability to communicate her contribution credibly, we are under no illusion that our (or any other) system of anonymity would be completely successful in keeping candidates uninformed. Some inventive donors, with the aid of inquiring candidates, will undoubtedly devise methods to signal credibly. ${ }^{81}$ For example, donors or candidates may bribe a representative of the blind trust to violate her fiduciary duty and disclose donor identities. ${ }^{82}$ Undoubtedly, incumbents will have an easier time than nonincumbents discovering the identity of their contributors because a previous history of giving provides a stronger basis for belief; nonincumbents often must start with no track record of fundraising. But simply relying on reputation will not suffice. A history of giving when donations were public does not create a very strong reputation for continuing to give once contributions become anonymous. Candidates will rightfully be concerned that even faithful contributors, once behind the cloak of anonymity, will decide to chisel on their past tradition of giving.

\section{Independent expenditures and issue advocacy.}

The most predictable evasions of mandated anonymity will be a substitution toward "independent expenditures" or "issue advocacy." The test for

81. Game theory suggests that publicly burning money might be effective in signaling a separate donation. Someone who says she gave $\$ 100,000$ and who publicly burns $\$ 10,000$ is more likely to have made the underlying gift than someone who merely says they gave $\$ 100,000$. Nevertheless, a nondonor might wish to get the benefits of a $\$ 100,000$ donation for just the $\$ 10,000$ price of burning some money. Independent expenditures, discussed in the next section, might be used as a surrogate for burning money.

82. The FEC could be empowered to audit campaigns for compliance with the anonymity regulations. Much like Fair Housing tests, such audits could determine whether campaign officials are willing to conspire with purported donors or trust representatives to learn donor identities. 
what constitutes independence turns on who controls the content of the speech. Independent expenditures-in contradistinction to "coordinated expenditures"-fund political expression that is not controlled by a candidate's campaign. Independent expenditures are made without "prearrangement and coordination." The test for "issue advocacy" turns on the content of the speech itself. Issue advocacy-in contradistinction to "express advocacy"does not expressly advocate the election of a particular candidate..$^{83}$

Because the Supreme Court has shown greater willingness to protect political speech that it deems either "issue advocacy" or an expenditure independent of the candidate's control, mandating donor anonymity for large gifts would undoubtedly cause more extensive use of these two end runs. And it is clear that independent expenditures and issue advocacy still pose some danger of corruption. "Candidates often know who spends money on their behalf, and for this reason, an [independent] expenditure may in some contexts give rise to the same reality and appearance of corruption." 84

As shown in Figure 1, these two dichotomous categories create four permutations of control and content. Coordinated express advocacy, like candidate express advocacy, is the most regulated type of political speech. One might initially predict a hydraulic response if donor anonymity were applied to this category: Every dollar of direct contribution that the donation booth deterred might simply reemerge in one of the three other boxes-as an independent expenditure, an issue advocacy campaign, or both. Recent history has already provided ample evidence of substitution toward these three categories. ${ }^{85}$ What's more, because candidates are not accountable for "independent" ad campaigns, these campaigns are likely to be particularly negative and reckless. It is not surprising, therefore, that the infamous "Willie Horton" ads were independent expenditures. ${ }^{86}$

If mandated anonymity is likely to produce anything like a dollar-fordollar hydraulic shift from direct contributions to independent expenditures or issue advocacy, the benefits of mandated anonymity reform would largely be lost. We believe, however, that (1) mandated anonymity can be extended

83. The distinction between issue advocacy and express advocacy is traceable to Buckley, 424 U.S. at $42-44 \&$ n.52.

84. Sunstein, supra note 15 , at 1395 (citation omitted). Sunstein admits that a candidate's knowledge of a donor's identity is a prerequisite for corruption, but he does not acknowledge that policies might limit a candidate's knowledge in order to deter comuption.

85. Both Clinton and Dole orchestrated the use of party soft money to fund coordinated issue campaigns. See Jill Abramson, 1996 Campaign Left Finance Laws in Shreds, N.Y. TIMES, Nov. 2, 1997 , at 1 (" $[\mathrm{T}]$ he Democratic committee spent at least $\$ 32$ million on early issue advertising. The advertisements, which began airing in mid-1995, were created by the Clinton-Gore team and prominently featured the President in patriotic settings."). Labor and business spent millions on independent issue campaigns in the 1996 election cycle. See Eliza Newlin Carney, Campaign Reform Debate Will Linger, 22 NAT'L J. 2026 (1997).

86. See Hasen, supra note 55, at 19 n.79. 
to reduce the possibility of an end run, and (2) where mandated anonymity is not constitutionally permissible, existing structural factors will ensure that independent or issue advocacy will not be a perfect substitute for corrupt, direct contributions.

\section{FIGURE 1}

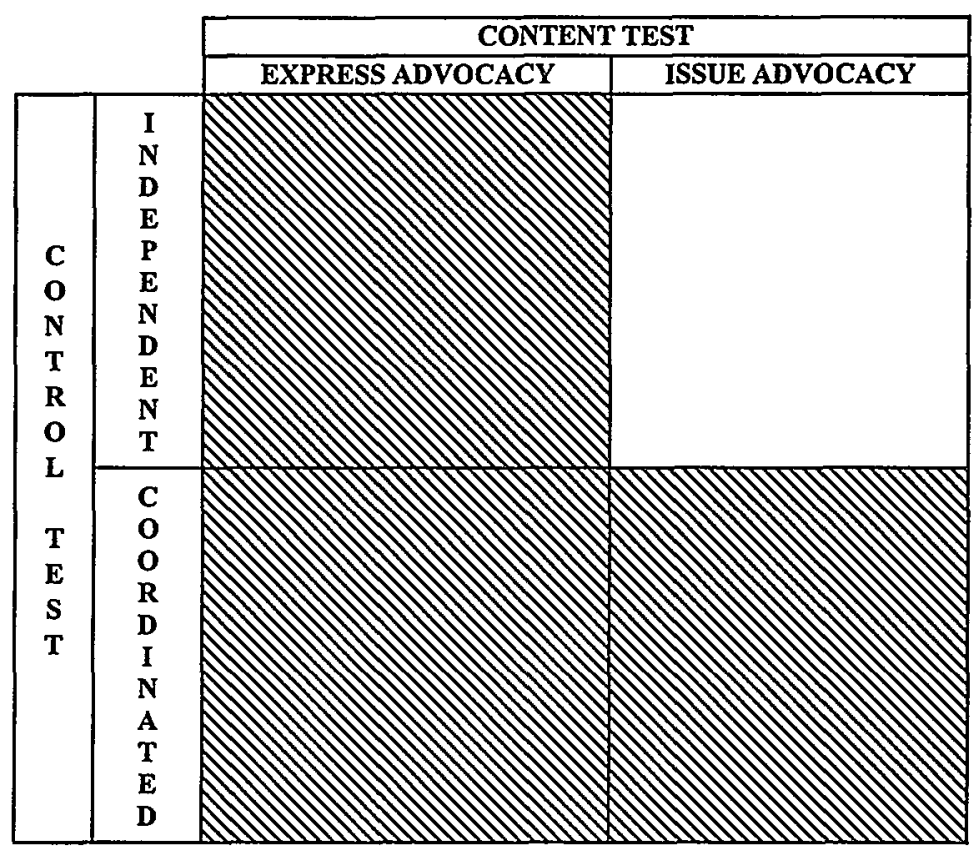

\begin{tabular}{|l|l|l|}
\hline LEGEND \\
\hline Mandated Contributor Anonymity \\
Constitutionally Permissible
\end{tabular}

What would it mean to extend mandated anonymity? To begin, it is straightforward to cover coordinated issue advocacy. As a constitutional matter, coordinated speech can be regulated as much as direct candidate 
speech. ${ }^{87}$ And although there is currently a lively debate about whether current law regulates coordinated issue advocacy, ${ }^{88}$ there is little question that, as a condition of taking federal money, candidates could be prohibited from coordinating issue advocacy campaigns. As we shall argue below, ${ }^{89}$ forcing all "soft money" contributions through blind trusts would dramatically reduce this current end run.

Independent express advocacy poses a harder problem. We suggest, however, that this circumvention could be substantially reduced by requiring that such campaigns be funded solely by contributions from individuals (not corporations or unions) funneled through blind trusts. ${ }^{90}$ Under such a regime, organizations could establish committees to orchestrate independent express advocacy ad campaigns, but the funding for such campaigns would need to come from individuals' donations to blind trusts. As with our earlier proposal, individuals would be able to communicate credibly that they had contributed (up to \$200) and thus, for example, have their names appear in a newspaper advertisement saying "we support candidate $x$." But such individuals would not be able to signal the amount of a large contribution.

Requiring that independent express advocacy be funded by individual anonymous donations would substantially reduce the viability of this circumvention. To be sure, some wealthy individuals would still be able to completely fund an independent express advocacy campaign.91 But given the costs of effective advertising, we predict that it would be difficult to raise individual contributions in the shadow of a blind trust. Those donors who are deterred by mandated anonymity from contributing directly to a candi-

87. See Colorado Republican Fed. Campaign Comm. v. FEC, 116 S. Ct. 2309, 2317 (1996) (plurality opinion) (indicating that the Court has treated coordinated expenditures as contributions, which Congress may constitutionally regulate).

88. See, e.g., Jill Abramson, Tape Shows Clinton Involvement in Party-Paid Ads: Legal Line Is Unclear, N.Y. TIMES, Oct. 21, 1997, at Al (discussing television issue ads that "advanced the Democratic Party's agenda as well as Mr. Clinton's").

89. See text accompanying notes 105-106 infra.

90. The constitutionality of blind trusts is discussed in detail in Part III.A. For now, we will simply point out that, in Austin v. Michigan State Chamber of Commerce, 494 U.S. 652, 654-55 (1990), the Supreme Court found it constitutionally permissible to prohibit independent political expenditures from a corporation's general treasury - as compared to a separate fund used solely for political purposes. And in Buckley, the Court upheld the constitutionality of mandated disclosure with regard to independent express advocacy. See Buckley v. Valeo, 424 U.S. 1, 80-82 (1976) (per curiam). We will argue below that our regime of mandated anonymity is a fortiori constitutional if mandated disclosure is constitutional. See text accompanying notes 177-194 infra. We would exempt ongoing news organizations from this obligation so that, for example, a newspaper could still endorse specific candidates.

91. For example, Michael R. Goland, "apparently motivated by the pro-Israel policies of Senators Paul Simon and Alan Cranston, funded large independent expenditure campaigns against their opponents." Hasen, supra note 55, at 19 n.79. Moreover, just as PACs now bundle individual contributions together to gain additional influence with politicians, see text accompanying notes 110-118 infra, we imagine that some independent express advocacy committees would bundle individual contributions together to gain similar influence. 
date's campaign are, for the most part, unlikely to give to a blind trust for independent express advocacy.

The most unyielding problem concerns substitution toward the upper right-hand box in Figure 1-that is, substitution toward independent issue advocacy. This combination of content and control has proven constitutionally unregulable. Buckley $v$. Valeo ${ }^{92}$ suggests that mandated disclosure of speaker identity is unconstitutional, and we believe that mandated anonymity would fare no better.

Still, some progress might be made by expanding the definition of what counts as express advocacy. The Supreme Court might accept a broader definition than the "magic words" test suggested in Buckley. ${ }^{93}$ The McCainFeingold Bill ${ }^{94}$ attempts just this broadening by defining as express advocacy any advertisements picturing or naming a candidate within thirty days of a primary election or sixty days of a general election. We support this effort. But instead of capping such expenditures or requiring disclosure of the names of those people who fund such campaigns, we suggest that mandating contributor anonymity would more effectively balance the government's interest in deterring corruption with the First Amendment interest in allowing unfettered discussion of political issues.

Even under the broadest imaginable constitutional definition of express advocacy, there will still be significant opportunity to use independent issue ads to affect the outcome of an election. ${ }^{95}$ But independent issue ads are not perfect substitutes for direct donations - especially donations made as part of quid pro quo corruption. As the Supreme Court has repeatedly emphasized:

92. 424 U.S. 1 (1976) (per curiam).

93. As Ronald Dworkin and Burt Neuborne have observed:

In FEC v. Massachusetts Citzens for Life, Inc., 479 U.S. 238 (1986), the Court found that a newsletter of a group was "express advocacy." The newsletter described the positions of certain candidates, labeling them "pro-life" and providing their pictures. The newsletter then urged the support of pro-life candidates generally. But it also contained an express disclaimer of endorsement of or opposition to any specific candidate. In deciding whether the speech fell on the electioneering side of the line, the Court relied on the "essential nature" of the message, and what it conveyed "in effect." Thus, it is the "essential nature" of a message, not the existence of "magic words," that determines whether speech is constitutionally regulable as electioneering, or free from regulation as issue advocacy.

Letter from Ronald Dworkin, Professor of Jurisprudence and Fellow of University College at Oxford University, Frank H. Sommer, Professor of Law, New York University School of Law, and Burt Neuborne, John Norton Pomeroy Professor of Law and Legal Director, Brennan Center for Justice, New York University School of Law, to Senators John McCain and Russell Feingold (Oct. 1,1997 ) (on file with the Stanford Law Review) (footnote omitted).

94. Bipartisan Campaign Reform Act of 1997, S. 25, 105th Cong. § 325(b)(1) (1997).

95. We note that our proposals would not relate to referenda, where the potential for corruption is attentuated. See First Nat'l Bank of Boston v. Bellotti, 435 U.S. 765, 790 (1978) (stating that the election of a candidate for public office raises a greater risk of comuption than a popular vote on a public issue). 
Unlike contributions, such independent expenditures may well provide little assistance to the candidate's campaign and indeed may prove counterproductive. The absence of prearrangement and coordination of an expenditure with the candidate or his agent not only undermines the value of the expenditure to the candidate, but also alleviates the danger that expenditures will be given as a quid pro quo for improper commitments from the candidate. ${ }^{96}$

This quotation nicely underscores the procedural and substantive differences between direct contributions and independent expenditures. Procedurally, the absence of prearrangement and coordination makes it more difficult for candidates and contributors to agree on the terms of quid pro quo corruption. The inability of candidates to solicit these expenditures, in particular, is likely to reduce a candidate's ability to extort (extract rent from) potential donors. Substantively, the absence of prearrangement and coordination makes it more likely that the independent expenditure will be spent differently than the candidate would have spent a direct contribution. The Supreme Court is overly sanguine in suggesting that, "[u]nlike contributions, such independent expenditures may well provide little assistance to the candidate's campaign and indeed may prove counterproductive."97 But because candidates would often use the money differently-for example, on express advocacy — candidates will tend to value $\$ 1,000,000$ of independent issue ads less than $\$ 1,000,000$ of direct contributions. ${ }^{98}$

Under a regime of mandated anonymity, candidates might still take positions in order to induce independent issue ads on their behalf (and vice versa), but the prohibition of both coordination and express advocacy acts as a tax on such indirect giving, tending to reduce its value to the candidate.

96. Buckley, 424 U.S. at 47; see also Austin v. Michigan State Chamber of Commerce, 494 U.S. 652, 702 (1990) (quoting Buckley); FEC v. National Conservative PAC, 470 U.S. 480, 497 (1985) (same). More recently, the Supreme Court has conceded that "the absence of prearrangement and coordination' does not eliminate, but it does help to 'alleviate,' any 'danger' that a candidate will understand the expenditure as an effort to obtain a 'quid pro quo."' Colorado Republican Fed. Campaign Comm. v. FEC, 116 S. Ct. 2309, 2316 (1996) (plurality opinion) (quoting National Conservative PAC, 470 U.S. at 498). Buckley's language itself undermines any strong claim that absence of coordination could eliminate the possibility of corruption. After "assuming, arguendo, that large independent expenditures pose the same dangers of actual or apparent quid pro quo arrangements as do large contributions," the Court says that "[i]t would naively underestimate the ingenuity and resourcefulness of persons and groups desiring to buy influence to believe that they would have much difficulty devising expenditures that skirted the restriction on express advocacy of election or defeat but nevertheless benefitted the candidate's campaign." Buckley, 424 U.S. at 45.

97. Buckley, 424 U.S. at 47.

98. An exception to this tendency might occur when the independent expenditure is used for purposes the politician supports, but doesn't want attributed to herself-for example, "going negative" by attacking her opponent. See text accompanying note 86 supra (discussing the Willie Horton ads). Yet the fact that independent expenditures are attributed to another speaker can often be a political liability. An independent ad campaign paid for by, say, Jane Fonda or tobacco interests might alienate as many voters as it persuades. Hence, independent expenditures by well-heeled but unpopular speakers would be much less valuable then direct contributions. 
Because mass communication exhibits dramatic economies of scale, it may be much more difficult for individuals who had been giving, say, $\$ 10,000$ or $\$ 20,000$ to the Democratic Party (and its candidates) to find an equally effective issue ad substitute. To be sure, independent issue ad organizations will start soliciting contributions, but these organizations are likely to find it more difficult to convince the erstwhile political donor to contribute.

While we concede that mandated anonymity would lead to an increase in independent issue ads, we simultaneously predict that a regime of mandated anonymity would nevertheless reduce quid pro quo and monetary influence corruption by reducing the overall level of direct and indirect contributionsi.e., both independent expenditures and issue advocacy. In the next two subsections, we try to provide more specific support for this prediction by showing how mandating donor anonymity can help mitigate two of the most abusive financing practices: soft money and PAC bundling.

\section{Soft money.}

Soft money contributions to political parties have become the primary route by which presidential candidates circumvent the contribution limits imposed by the Federal Election Campaign Act ("FECA").99 Even though soft money contributions, in theory, are supposed to be used for general party-building activities (such as voter registration and "get out the vote" drives), ${ }^{100}$ in practice, political parties devised ways to use the money to promote federal candidates. ${ }^{101}$

What began as a narrow exception is now a large loophole growing wildly out of control:

[During the 1996 election cycle,] Republican national committees raised about $\$ 141$ million for their soft-money accounts ... an increase of 183 percent over the same time period in the 1991-92 election cycle, [and] Democratic national committees raised about $\$ 122$ million during this same period, a 217 percent jump from the amount raised during the 1991-92 election cycle. ${ }^{102}$

99. 2 U.S.C. $\S 431$ (1994).

100. Cf. id. $\S 431(8)(b)$ (xii) (excluding from FECA's definition of "contribution" "the payment by ... a political party of the costs of voter registration and get-out-the-vote activities ... on behalf of nominees of such party for President and Vice President").

101. For example, in the 1996 election, an estimated $\$ 50,000,000$ to $\$ 75,000,000$ of soft money was spent on delivering "educational" messages to voters. See Editorial, Next Round for Campaign Reform, N.Y. TimES, Sept. 3, 1997, at A18; see also Hasen, supra note 55, at 20 n.86 ("Senator Bob Packwood's diaries reveal how easily soft money may be diverted to federal campaigns.").

Presidential candidates, in particular, have significant control over how their national party committees spend soft money. Accordingly, $\$ 1,000,000$ of soft money is likely to be much more valuable to a candidate than $\$ 1,000,000$ of independent expenditures.

102. Russell Feingold, Modest Reform?, Boston REV., Apr.-May 1997, at 9. 
Moreover, soft money contributions are particularly likely to breed corruption of either the quid pro quo or monetary influence variety. Soft money contributions are disproportionately large-often reaching six figures. ${ }^{103}$ Soft money contributors are often corporations and unions trying to circumvent direct contribution limits or business executives with targeted legislative agendas. ${ }^{104}$ And most importantly for our purposes, "candidates know . . . the identity of the large contributors to the party, and for this reason soft money can produce risks of corruption."105

But there is no reason why candidates need to know the identity of large party contributors. By simply funneling soft money contributions to political parties through blind trusts, we could radically reduce the potential for corruption. Corporations and unions would not make large soft money contributions in the hopes of gaining access or influence if candidates could not learn the identities of the party's donors.

The McCain-Feingold campaign finance reform bill valiantly tries to "ban" soft money contributions. ${ }^{106}$ But it is exceedingly difficult to craft a ban that is constitutional. ${ }^{107}$ To date, the only response from the Federal

103. Overall, " 69 contributors gave $\$ 100,000$ or more each to the Bush-RNC efforts during the 1991-1992 election cycle, and 72 contributors gave $\$ 100,000$ or more each to the Clinton-DNC efforts during the 1991-1992 election cycle." Fred Wertheimer \& Susan Weiss Manes, Campaign Finance Reform: A Key to Restoring the Health of Our Democracy, 94 CoLUM. L. REv. 1126, 1147 (1994) (citing Soft Money for President Clinton \& Democratic National Committee Tops \$29 Million During 1991-1992 Election Cycle, CoMmON CAUSE NEWS, Mar. 3, 1993, at 2, and Soft Money to Republican National Committee \& Bush Tops $\$ 32$ Million During 1991-1992 Election Cycle, COMmon CAuSE News, July 23, 1993, at 3) (footnote omitted). As Wertheimer and Manes point out:

It is important to note that these figures represent the soft money contributions reported by the national party committees to the FEC and are not complete soft money totals for the 1992 presidential election. In 1988, for example, a number of soft money contributions raised by the presidential campaigns went directly to the state political party committees. Such contributions are not included in the FEC reports filed by the national party committees.

Wertheimer \& Manes, supra, at 1147 n.115.

104. See Next Round for Campaign Reform, supra note 101, at A18.

105. Sunstein, supra note 15 , at 1409 . Here we part company with the analysis in Colorado Republican: "[T]he opportunity for corruption posed by these greater opportunities for ['soft money'] contributions is, at best, attenuated. Unregulated 'soft money' contributions may not be used to influence a federal campaign, except when used in the limited, party-building activities specifically designated in the statute." Colorado Republican Fed. Campaign Comm. v. FEC, $116 \mathrm{~S}$. Ct. 2309, 2316 (1996) (plurality opinion). The Court's analysis, however, was based on an empirical assumption that has proved false. Thus, consistent with stare decisis, it may revisit the issue.

106. See Feingold, supra note 102 , at 9.

107. The Bill requires that party expenditures "for any activity that might affect the outcome of a Federal election, including any voter registration or get-out-the-vote activity, any generic campaign activity, and any communication that refers to a candidate," must count against the party's contribution limit. Bipartisan Campaign Reform Act of 1997, S. 25, 105th Cong. § 325(b)(1) (1997). Besides the important issue of whether this standard-"any activity that might affect"-is unconstitutionally vague, the party could still arbitrarily allocate significant expenditures across many of its federal candidates, even though it intended the primary beneficiary to be the presidential candidate. After the Supreme Court's recent Colorado Republican decision, neither the McCain- 
Election Commission ("FEC") to the soft money problem has been to require greater disclosure of soft money contributions. ${ }^{108}$ We suggest that, instead of proceeding further down the path of disclosure, lawmakers should reverse direction by mandating donor anonymity for all substantial party contributions. A regime of mandated anonymity could radically reduce the corrupting influence of soft money without the constitutional questions raised by an outright ban. ${ }^{109}$

\section{PAC bundling.}

The regime of mandated donor anonymity would also put an end to the campaign finance abuse commonly referred to as "PAC bundling":

The loophole, called bundling, works in the following way: a PAC, for example, solicits contributions from its members made out to a particular candidate and then turns over these contributions or otherwise arranges for them to be channeled to that candidate. Because the contributions technically originate with the person who signs the contribution check, the contributions involved do not count toward the $\$ 5,000$ limit on the amount the PAC can contribute to a candidate. The PAC, however, gets the credit-and the influence that flows from it-for giving the total amount of bundled contributions to the candidate. Bundling thereby effectively allows the PAC to evade its contribution limits. ${ }^{110}$

The extent to which PACs have used bundling to exceed their $\$ 5000$ contribution limit has been staggering at times. For example, in the mid-1980s, an insurance PAC bundled more than $\$ 168,000$ of individual contributions together with the PAC's own $\$ 1000$ contribution to a single

Feingold Bill nor any other statute can limit a party's ability to make independent expenditures. See Colorado Republican, 116 S. Ct. at 2315-17.

108. See 11 C.F.R. $\S \S 104.8$ (a)-(b) (1997) (requiring national party committees to disclose the names of individuals contributing more than $\$ 200$ ); see also Wertheimer \& Manes, supra note 103, at 1146 (discussing the "requirement that national party committees disclose soft money contributions").

109. Mandated anonymity regulations would be particularly important if the Supreme Court were to strike down the current limits on coordinated party expenditures. In Colorado Republican, four Justices indicated a willingness to extend constitutional protection to "political party spending 'in cooperation, consultation, or concert with' a candidate"-whether in the form of uncoordinated expenditures, coordinated expenditures, or contributions. Colorado Republican, $116 \mathrm{~S}$. Ct. at 2322 (Kennedy, J., concurring in part and dissenting in part) (quoting 2 U.S.C. $\$ 441 \mathrm{a}(\mathrm{a})(7)(\mathrm{B})(\mathrm{i})$ (1994)). Justice Thomas, in a separate opinion, also concluded that limiting party-to-candidate contributions would be constitutional. See id. at 2330-31 (Thomas, J., concurring in part and dissenting in part). Chief Justice Rehnquist and Justice Scalia joined both opinions on this point. See id. at 2321, 2323; see also Note, Parties, PACs, and Campaign Finance: Preserving First Amendment Parity, 110 HARV. L. REV. 1573, 1573 (1997). Unregulated party-to-candidate contributions or coordinated expenditures by parties could lead to massive evasions of the current individual contribution limits because FECA allows individuals to give 20 times more to political parties than to individual candidates. Mandated anonymity might deter much of this evasion by reducing donors' general interest in making substantial contributions.

110. Wertheimer \& Manes, supra note 103, at 1140-41 (footnotes omitted). 
member of Congress. ${ }^{111}$ The National Republican Senatorial Committee ("NRSC") bundled more than $\$ 6,000,000$ to 1986 candidates. EMILY's List, not to be outdone, "used the bundling loophole to become the largest House and Senate PAC contributor in 1992, reportedly bundling some $\$ 6$ million to congressional candidates." 112

The bundling loophole has substantially increased the influence of PACs, as well as the likelihood of political corruption. ${ }^{113}$ The problem with PAC bundling is not that it leads PACs to misrepresent donors' policy preferences, but that it allows groups of individual contributors to buy access or influence. As Cass Sunstein has noted, "[PAC contributions] are particularly likely to be given with the specific purpose of influencing lawmakers. It is also the case that candidates who receive individual contributions are often unaware of the particular reason for the money, whereas PAC beneficiaries know exactly what reasons underlie any donation."114 Beyond the most outrageous forms of quid pro quo corruption, candidates quickly learn that adopting particular positions translates, literally, into bundles of contributions.

Our proposed regime of mandated donor anonymity would effectively outlaw bundling. A PAC could not take possession of checks made out to particular campaigns, and these campaigns could not accept checks from a PAC (or anyone else). ${ }^{115}$ The PAC could still solicit funds for any candidate it supports, but the individual donors would then need to send their checks by

111. See Brooks Jackson, Insurance Industry Boosts Political Contributions As Congress Takes Up Cherished Tax Preferences, WALL ST. J., Oct. 10, 1985, at 64.

112. Wertheimer \& Manes, supra note 103, at 1141 (citing Helen Dewar, EMILY's List Falls Prey to PAC Hunt, WASH. POST, Mar. 7, 1993, at C1, and Thomas B. Edsall, Campaign Skirts Rules by "Bundling" Contributions, WASH. POST, Oct. 20, 1986, at A8).

Corporate PACs have been particularly successful at bundling together the contributions of their senior executives and middle management. See generally Kenneth A. Gross, The Corporate PAC: Should We PAC It In?, 34 FED. B. NEwS \& J. 63 (1987). For example, the New York investment banking firm of Goldman, Sachs \& Co. contributed nearly $\$ 450,000$ to congressional candidates during the 1990 election, most of it by bundling individual contributions. See Sara Fritz, Study Reveals New Trend in Lobbying, L.A. TIMES, July 1, 1992, at A18; see also Lisa B. Bingham, Employee Free Speech in the Workplace: Using the First Amendment As Public Policy for Wrongful Discharge Actions, 55 OHo ST. L.J. 341, 358-59 (1994) ("Under federal law, the corporate PAC may solicit employees as frequently as twice a year for donations, provided it informs the employees that donations are voluntary.").

113. See Vincent Blasi, Free Speech and the Widening Gyre of Fund-Raising: Why Campaign Spending Limits May Not Violate the First Amendment After All, 94 COLUM. L. REV. 1281, 1321 (1994) ("Currently much of the time of candidates is spent courting not the donors themselves but brokers who arrange events at which individual and PAC contributions are made, or who actually collect 'bundles' of such contributions and transmit them to candidates."); see also Hasen, supra note 55, at 19 ("By aggregating the donations of individual contributors, [PACs] have arguably become "the new fat cats of American campaign finance." (quoting SORAUF, supra note 28, at 126)).

114. Sunstein, supra note 15 , at 1409.

115. See text accompanying note 64 supra. 
mail directly to the candidate's blind trust. ${ }^{116}$ PAC bundling is fundamentally a problem of too much information, and as in other contexts, mandated anonymity provides the appropriate solution.

The problem of PAC bundling is not that PACs successfully solicit contributions from individuals, but that the PACs get "the credit-and the influence that flows from it."117 The problem is informational: PACs make damn sure that candidates know which PAC produced the bundle. The impetus to prohibit bundling (contained in several proposals ${ }^{118}$ ) is fundamentally a movement to mandate bundling anonymity. PACs would still be allowed to solicit individual contributions exceeding the amount that a PAC could give directly, but bundling anonymity would keep the candidate from learning that the PAC was responsible for this fundraising.

\section{Evidence from judicial elections.}

To assess the feasibility of an anonymous regime, it is useful to look at what amounts to a limited experiment with mandated anonymity in judicial elections. The commentary to the 1972 Code of Judicial Conduct ("CJC") stated, "[T]he [judicial] candidate should not be informed of the names of his contributors unless he is required by law to file a list of their names."119 As with our proposal, the impetus behind the CJC's call for anonymity was to reduce the potential for corruption. ${ }^{120}$ The 1972 commentary was subse-

116. See id. Thus, even if a donor wrote a check in the presence of a PAC representative, the check would have to be mailed by the donor-who would always have 10 days to cancel her contribution. See text accompanying note 72 supra.

117. Wertheimer \& Manes, supra note 103, at 1141. "The bundling loophole poses a serious threat to the integrity of existing federal contribution limits and the ability of these limits to protect the political system from potential corruption as a result of large political contributions." Id. at 1142.

118. See, e.g., Geoffrey M. Wardle, Note, Political Contributions and Conduits After Charles Keating and EMILY's List: An Incremental Approach to Reforming Federal Campaign Finance, 46 CASE W. RES. L. REV. 531, 571-76 (1996) (advocating incremental reforms aimed at eliminating bundling).

119. E. WAYNE THODE, REPORTER'S NOTES TO CODE OF JUDICIAL CONDUCT 99 (1973).

120. As explained by one scholar:

Subsection $\mathrm{B}(2)$ has one sentence of commentary, which explains to a far greater extent than the text the theory underlying the CJC's approach to campaign financing ..... With a committee acting as a buffer between the contributor and the candidate, the candidate will, in theory, never know who contributed to his campaign. No bias can creep into the judge's decisionmaking, and neither the parties nor the onlooking world can perceive the appearance of bias.

Stuart Banner, Note, Disqualifying Elected Judges from Cases Involving Campaign Contributors, 40 STAN. L. REV. 449, 470 (1988); see also 1978 N.Y. ST. COMM. ON JUD. CONDUCT ANN. REP. 63 (1979) ("The intent behind keeping a judge from knowing his contributors is obvious: to avoid the impression that, if elected, the judge will administer his office with a bias toward those who supported his candidacy."). 
quently adopted —and, to varying degrees, applied - in ten different states. ${ }^{121}$

Several commentators have opined that post-Watergate campaign disclosure laws passed by all fifty states have "rendered useless ... the Code's policy of keeping contributors' identities from judges' attention."122 This widely accepted belief that campaign disclosure laws made the judicial disclosure laws unnecessary led the committee revising the Code to drop the anonymity requirement from the 1990 Model Code of Judicial Conduct. ${ }^{123}$ But this underlying belief was erroneous. Three factors combined to give the judicial anonymity requirement varying degrees of continuing effect. First, the campaign disclosure laws were not passed in some jurisdictions until years after the judicial disclosure laws were adopted. ${ }^{124}$ Second, in some states, the campaign disclosure statutes only apply to political candidates, not to judicial candidates. ${ }^{125}$ And finally, some states' campaign disclosure laws

121. See Banner, supra note 120 , at 473 n.130 (identifying the 10 adopting states as Arkansas, Nebraska, North Dakota, South Carolina, South Dakota, Tennessee, Utah, Washington, West Virginia, and Wyoming).

In addition, the Colorado Code of Judicial Conduct included a provision that judicial candidates "should not be advised of the source of any campaign contributions." Leona C. Smoler \& Mary A. Stokinger, Note, The Ethical Dilemma of Campaigning for the Judicial Office: A Proposed Solution, 14 FORDHAM URB. L.J. 353, 378 (1986) (citing CODE OF JUDICLAL CONDUCT Canon 7B(2), Colo. Rev. STAT., COURT Rules ch. 24 app. (Supp. 1984)).

The Detroit Bar Association proposed a system of mandated donor anonymity, marketed under the name of the "Fair Plan." See Barbara Schulert, "Fair Plan" for Campaign Gifts Delayed in Detroit, 60 JUDICATURE 194, 194 (1976). Under the Detroit plan, a "group of unpaid trustees (including at least one nonlawyer) would have forwarded contributions anonymously from participating lawyers to participating judicial candidates." Id. The plan was wholly voluntary, in that only "participating" candidates would be precluded from accepting contributions from lawyers outside of the plan. Cf. Victor J. Baum, Should Judges Know Who Gave to Their Campaigns?, 60 JudicATURE 258, 258 (1977). But the plan was never put into effect. See Smoler \& Stokinger, supra, at 364. In 1972, the Dade County (Miami) Bar Association established blind trusts for judicial candidates. But the Dade County plan did not allow contributors to earmark funds for a specific candidate. Instead, all candidates whom the Dade County Bar Association rated as "qualified" shared in the trust proceeds. See Schulert, supra, at 194.

122. Bradley A. Siciliano, Note, Attorney Contributions in Judicial Campaigns: Creating the Appearance of Impropriety, 20 HOFSTRA L. REV. 217, 220 (1991) (footnote omitted); see also Banner, supra note 120, at 471 ("All fifty states and the District of Columbia require candidates for elective office to file reports disclosing all campaign contributions and, for contributions over a certain amount, the names of contributors."); Mark Andrew Grannis, Note, Safeguarding the Litigant's Constitutional Right to a Fair and Impartial Forum: A Due Process Approach to Improprieties Arising from Judicial Campaign Contributions from Lawyers, 86 MicH. L. REV. 382, 385 (1987) ("[A]ll fifty states currently require disclosure of all contributions and the names of those who contribute more than a minimum amount.").

123. See Lisa L. Milord, The DevelopMENT of the ABA Judicial CODE 55 (1992) ("The sentence prohibiting the revelation to the candidate of the names of contributors to the candidate's campaign was deleted, because most jurisdictions now require candidates to disclose the names of their campaign contributors.").

124. For example, in West Virginia, the Commentary to the CJC became effective on January 1, 1973, see JUdicial CODE OF ETHICS, W. VA. CODE editor's notes (1994), but the campaign disclosure law did not become effective until 1976, see W. VA. CODE § 3-8-5a (1994).

125. See, e.g., N.D. CENT. CODE § 16.1-08.1-02 (1991). 
only require that an officer of the campaign committee-as distinguished from the candidate herself - file a list of contributors' names and amounts given. ${ }^{126}$ The candidate's ignorance can be preserved under this system because she is only required to sign a form disclosing the total amount contributed to her campaign. Such a situation does not trigger the "unless" clause exception to the 1972 anonymity requirement because the judicial "candidate is [not] required by law to file a list of his campaign contributors"- - only her treasurer is.

Letter opinions of state judicial ethics committees address what judicial campaign committees need to do to keep candidates uninformed. The existence of such letters indicates that at least some states have taken the anonymity requirement seriously. For example, some states have allowed fundraising dinners only where "the judge does not attend the dinner or otherwise participate in any way in the solicitation effort."127 In one instance, "a judge sent a video tape of himself to a fund-raiser held on his behalf, thanking all the attendants, and thereby avoiding a breach of anonymity of contributors." 128 Several of the rules are consonant with our own implementation proposals. New York allowed judicial candidates to appear at a fundraiser, provided no fee was charged for attendance, and the candidates left before any donations were solicited. ${ }^{129}$ And North Dakota required the campaign treasurer to establish a post-office box outside the candidate's control to receive all contributions. ${ }^{130}$

126. See, e.g., 1984 N.Y. ST. COMM. ON JUD. CONDUCT ANN. REP. 75-76 (1985).

127. Ga. Jud. Qualifications Comm'n Op. 7 (1976); see also La. Sup. Ct. Comm'n on Jud. Ethics Op. 11 (1973) (arguing that candidates should "avoid receiving information as to persons and organizations who contribute to the testimonial and persons and organizations who do not").

128. Siciliano, supra note 122, at 220 n.22 (citing Sheila Macmanus, 11th National Conference Convened, 10 JUD. CONDUCT REP. NO. 3, at 3 (1988)). Jurisdictions that adhere to nondisclosure rules have required that candidates not be informed about who purchases tickets to fundraisers and have even gone so far as to require that the tickets not be numbered. See James J. Alfini \& Terrence J. Brooks, Ethical Constraints on Judicial Election Campaigns: A Review and Critique of Canon 7, 77 KY. L.J. 671, 715 (1989). 'Numbering solicitations or tickets to fundraising events may create the perception that a record is kept of those who attend that is passed along to the candidate." Id. at 715 n.243 (citing La. Sup. Ct. Comm'n on Jud. Ethics Op. 56 (1973); La. Sup. Ct. Comm'n on Jud. Ethics Op. 11 (1973)).

129. See 1984 N.Y. ST. COMM'N ON JUD. CONDUCT ANN. REP. 77 (1985). Several commentators have suggested that a candidate can infer her donors' identities by seeing who is in attendance at a fundraiser. A judge commented that anonymity "is fiction because pragmatically even though you may not know who has or how much has been contributed by your appearance [at a fundraiser], it ... would permit you to favor those who attended." Smoler \& Stokinger, supra note 121 , at 394; see also Grannis, supra note 122, at 385 (arguing that anonymity is "nearly impossible" to enforce). But as long as nondonors can just as easily put in an appearance as a bona fide donor, it will be difficult for the candidate to know whom to favor.

130. See Interview with Corey Wills, Secretary of North Dakota State Election Department, in Champaign, Ill. (Aug. 15, 1997). 
Have these requirements of anonymity kept judges uninformed? Several judges have answered in the affirmative. ${ }^{131}$ And the commentary to the original 1972 CJC opined that "[a] similar nondisclosure provision has worked effectively in the state of Washington."132 If judges were kept uninformed, the overall amount of giving should have decreased: Lawyers who had been giving solely to influence future judicial behavior would stop giving under an effective anonymity regime. ${ }^{133}$ Although empirical testing of our prediction is still needed, ${ }^{134}$ we can report that at least one judge believes donor anonymity is "definitely inappropriate [because] his supporters would not have contributed to his campaign had they been aware that he was forbidden from learning their names." 135

But both the effectiveness and appropriateness of the anonymity requirement are controversial. The committee for the 1990 revision of the CJC "found it unrealistic and inadvisable to prohibit disclosure of contributors'

131. See, e.g., Interview with Judge Thomas E. McHugh, West Virginia 13th Circuit, in Charleston, W. Va. (Aug. 10, 1997); Interview with Justice Pamela B. Minzner, New Mexico Supreme Court, in Santa Fe, N.M. (Aug. 20, 1997).

132. THODE, supra note 119 , at 99.

133. The two most infamous examples of monetary influence-if not quid pro quo-corruption concem the donations of Joseph D. Jamail and the acceptance of gifts by New York County Surrogate Marie M. Lambert. Immediately after the highly publicized Pennzoil-Texaco case had been assigned to Texas District Court Judge Anthony J.P. Farris, Pennzoil attomey Joseph D. Jamail contributed $\$ 10,000$ to Farris's reelection campaign. One paper noted that "Jamail's contribution [to Farris] raised eyebrows, because Jamail is a liberal Democrat while Farris . . . was a conservative Republican." Tom Moran, Attorney's Contributions to Judges Have Some Calling Foul, HOUS. CHRON., June 28, 1987, at 16. When Texaco's attempt to disqualify Jamail was unsuccessful, both Texaco and Pennzoil began what seemed to be an "arms race"-using campaign contributions-to control the hearts and minds of the Texas judiciary. As the case approached the Texas Supreme Court, the two litigants and their lawyers contributed more than $\$ 380,000$ to the campaign funds of Texas Supreme Court justices. See Banner, supra note 120, at 451; Nicholas C. McBride, Pressure Grows in Legal Profession to Get Judges out of Politics, CHRISTIAN SCI. MONITOR, Aug. 14,1987 , at 5 .

An even more egregious example of monetary influence corruption concerns New York County Surrogate Marie M. Lambert. In what, to date, seems to be the only reported decision referring to a violation of Canon 7B(2)'s anonymity requirement, the New York State Commission on Judicial Conduct instituted proceedings against Surrogate Lambert for, inter alia, "acquaint[ing] herself with the identities of her contributors." Nicholson v. State Comm'n on Judicial Conduct, 422 N.Y.S.2d 701, 704 (N.Y. App. Div. 1979). Some lawyers were eager to contribute to Lambert's campaign because she, as surrogate, doled out lucrative guardianship assignments. It is reported that "[f]rom 1984 to 1987 , one campaign worker received over $\$ 24,000$ in guardianship fees; another supporter received over $\$ 72,000$." Banner, supra note 120 , at $471 \mathrm{n} .121$; see also Claudia Weinstein, Catalfo Leads Pack in Guardian Fees, MANHATTAN LAW., Nov. 10, 1987, at 10 (noting that Lambert awarded $\$ 113,320$ in guardianship fees to Vincent Catalfo, who had been subpoenaed in connection with an earlier investigation into Lambert's campaign violations).

134. We had hoped to test whether overall giving and inequality in size of donations declined in a jurisdiction once anonymity was required. But to date, we have been unable to acquire the appropriate data.

135. Smoler \& Stokinger, supra note 121, at 393. 
names."136 Surveys indicate that elected judges are equally divided about whether they should learn the identity of their donors. ${ }^{137}$ Many academics disfavor the anonymity requirement, primarily based on the widespread belief that campaign disclosure statutes have rendered anonymity impossible. ${ }^{138}$

On this record, there are no easy conclusions to be drawn from the judicial experience with mandated anonymity. The judicial implementations didn't go far enough to assure anonymity. State committees on judicial ethics often had little power to back up the CJC's anonymity requirement. ${ }^{139}$ The blind trusts were administered by campaign treasurers who had intimate ties with the candidates, ${ }^{140}$ and in states requiring the treasurer to file detailed disclosures, the press might bring to a judge's attention what an ethical treasurer had not. ${ }^{141}$ One judge, commenting on the difficulties of remaining ignorant, said:

[T] je judicial candidate cannot disentangle himself from the financial aspects of his campaign. I know, because I tried hard to do so. A citizens committee did all the solicitation, so that I was spared asking anyone to contribute; a secretary for the committee wrote the letters acknowledging the contributions; and the committee treasurer prepared and filed the reports required by Pennsylvania

136. MILORD, supra note 123 , at 55 . The committee reasoned that anonymity was inadvisable "because a judge should know of any contribution that would require the judge's recusal in a particular matter." Id. However, this normative argument is unpersuasive: Under an anonymity regime, a judge would not know who contributed to her campaign and therefore donations could not improperly influence her. See Maura Anne Schoshinski, Towards an Independent, Fair, and Competent Judiciary: An Argument for Improving Judicial Elections, 7 GEO. J. LEGAL ETHICS 839, 852, 857 (1994) (discussing the committee's reaction to disclosure requirements).

137. A 1985 nationwide survey of 488 elected judges found that $54 \%$ believed that "a judicial candidate should be permitted to know the names of the individuals who provide campaign funds for his/her own election campaign." Smoler and Stokinger, supra note 121, at 393. Twenty-two percent of respondents believed that knowing the names of donors was definitely appropriate, and $23 \%$ believed it to be definitely inappropriate. See id.

138. See, e.g., Banner, supra note 120, at 470 ("The Code is a great idea, except for one problem. It doesn't work."); Grannis, supra note 122, at 385 ("Contributor anonymity is thus nearly impossible to enforce."); Schoshinski, supra note 136, at 857 ("Initially . . . this system offers an attractive solution; however its appeal pales when compared with the great difficulty in implementing [it].")

139. For example, while Canon $7 \mathrm{~B}(2)$ applies to all candidates for judicial office, state judicial conduct commissions only have jurisdiction over judicial officers; violations by losing candidates could not be sanctioned. See Smoler \& Stokinger, supra note 121, at 383-84.

140. In contrast, we have proposed that trusts be administered by representatives of large, seasoned trusts who forswear contact with the candidate or members of her campaign staff. See text accompanying notes 60-61 supra.

141. See 1978 N.Y. ST. COMM. ON JUD. CONDUCT ANN. REP. 63 (1979) ("The requirement of public filing practically defeats that intent [of anonymity]."); see also Banner, supra note 120, at 472 n.123; Rick Karl, Electing Supreme Court Justices-For the Last Time, 60 JUDICATURE 290, 291-92 (1977) (discussing the conflict in the context of the 1976 Florida Supreme Court elections); Schoshinski, supra note 136, at 857 ("[W]ith the requirement of public disclosure, there is no guarantee that the media will not publish the lists of contributors."). 
election law. As a result, in general I did not know who gave me money. Nevertheless, ... . sometimes by accident, I learned of contributions by others. ${ }^{142}$

While disclaiming the effectiveness of the anonymity requirement, the judge's observation nonetheless suggests that the rule had some effect. The evidence from judicial elections suggests that, at the very least, it is possible to induce a certain amount of voluntary compliance.

In this section, we have described in more detail how a regime of mandated anonymity might operate. Anonymity regulation would predictably lead to more independent expenditures and issue advocacy, but it would substantially reduce the number of six-figure soft money gifts, as well as eliminate the current PAC bundling abuse. In the end, we believe that any regime of mandated anonymity is likely to be a leaky information bucket. But on net, mandated anonymity is likely to substantially reduce the prevalence of large contributions by disrupting the market for monetary influence. If anything, we worry that the proposal may be too effective, making it too hard for candidates to finance their campaigns.

\section{Is the Game Worth the Candle?}

A donation booth scheme is not a panacea. This section will identify three additional drawbacks of the scheme.

In Part I, we rejected the notion that a candidate had a legitimate interest in learning the identity of her contributors. But in withholding this information from the candidate, the donation booth also denies information to voters and donors. Here we consider whether preventing these people from learning donor identities undermines the usefulness of our proposal. But first we consider an even more fundamental problem: whether anonymity would limit a candidate's ability to speak.

\section{Less candidate speech.}

The claim that mandated anonymity could cause a campaign-financing crisis must be taken seriously. Anonymity exacerbates the donor's paradox for large donors and might lead to a dramatic drop-off in giving. ${ }^{143}$ As a general matter, donors like to be recognized for their charity. ${ }^{144}$ The dona(1976).

142. Edmund B. Spaeth, Jr., Reflections on a Judicial Campaign, 60 JUdICATURE 10, 14

143. As argued above, however, mandated anonymity might mitigate the donor's paradox for relatively small contributors because, under an anonymity regime, small contributions have greater relative significance. See text accompanying notes 46-47 supra.

144. Donors often explicitly bargain for public acknowledgment of their gifts. See, e.g., Allegheny College v. National Chautauqua County Bank of Jamestown, 246 N.Y. 369, 375 (N.Y. 1927) (involving a condition that the donor's gift "be known as the Mary Yates Johnston Memorial Fund"). In Allegheny College, Justice Cardozo held that acknowledging a promised gift under a 
tion booth may have an overbreadth problem in that contributors who currently give, in part, to acquire status among their peers may be deterred from giving through blind trusts. Even donors who are not motivated by a desire to corruptly influence policy may thus be chilled by mandated anonymity.

Access to the media requires funding. A reduction in donations could mean a reduction in media access. In this regard, mandated anonymity could limit a candidate's ability to speak - and the public's right to listen. Indeed, the very uncertainty of the effect of mandated anonymity on contributions could give policymakers pause. ${ }^{145}$

A related concern is that, by reducing the ability of candidates to speak, mandated anonymity will unduly increase the influence of other speakers, such as the media, unions, and rich, self-funded candidates. Media speech, the quintessential independent expenditure, will go unregulated under any reform proposal. ${ }^{146}$ We might worry about who will be next in line to influence the candidate corruptly if anonymity undermines the influence of large donors. Candidates unable to sell influence in exchange for contributions might begin to kowtow to the imagemakers of the mass media. It might be better to countenance the undue influence of large donors under the current system than to transfer this influence to an even smaller media oligarchy. Under this theory, the contributions of James Riady and the millions of other millionaires among us may provide a Jeffersonian counterweight against the potentially disproportionate influence of Citizens Hearst or Murdoch - or the even less accountable corporations and unions that bankroll issue ads. ${ }^{147}$

Nevertheless, facilitating quid pro quo and monetary influence corruption is too high a price to pay for political speech. If noncorrupting private donations do not sufficiently fund campaigns or offset the undue influence of

donor's name created an enforceable bilateral contract. See id. at 377; see also Amihai Glazer \& Kai A. Konrad, A Signaling Explanation for Charity, 86 AM. ECON. REv. 1019, 1021 (1996) (noting that fewer than one percent of the donations to Yale Law School, Harvard Law School, and Carnegie Mellon University are anonymous); Eric A. Posner, Altruism, Status, and Trust in the Law of Gifts and Gratuitous Promises, 1997 WIS. L. REv. 567, 574 n.17 ("Charitable gifts are rarely made anonymously.").

145. The desire for public recognition also leads most people to make gifts at the lowest end of each published category of contributions. See Glazer Konrad, supra note 144, at 1021 (noting that $93 \%$ of those contributing to the Harvard Law School Fund category of $\$ 500-\$ 999$ made contributions of $\$ 500$ ). Since $\$ 200$ is the maximum provable contribution under our proposal, this amount might become the common donation amount. Under the current regime, more than $80 \%$ of federal contributions are over $\$ 200$, so a regime that prohibits distinctions among contributions over $\$ 200$ might result in a substantial reduction in donations.

146. Cf. Ackerman, supra note 3 , at 78 (noting that the Supreme Court would invalidate expenditure limitations that limit free speech).

147. The Washington Times reports that more than $\$ 800,000$ in contributions to the Democratic National Committee have been traced to Riady. See Donald Lambro, Senate Hearings Raise Eyebrows, WASH. TIMES, July 20,1997, at A1. More than 2,000,000 Americans have a net worth of over \$2,500,000. See Richard Todd, Who Me, Rich?, WORTH, Sept. 1997, at 70, 73. 
media moguls, we should supplement private contributions with public money. ${ }^{148}$

\section{Less donor information for voters.}

Mandated anonymity keeps voters-as well as candidates-in the dark about donors' identities. Denying voters this information could be problematic. The Supreme Court in Buckley identified two adverse effects:

[Disclosing the identity of a candidate's donors] allows voters to place each candidate in the political spectrum more precisely than is often possible solely on the basis of party labels and campaign speeches. The sources of a candidate's financial support also alert the voter to the interests to which a candidate is most likely to be responsive and thus facilitate predictions of future performance in office. ${ }^{149}$

The second advantage of donor identity is absent under a system of mandated anonymity: Candidates are not "more likely to be responsive" to donors if they don't know who their donors are. Moreover, it is unclear whether the first effect of donor identification-more precisely placing the candidate in the political spectrum-should be classified as an advantage. It might be more conducive to democratic deliberation for voters to learn about a candidate's positions on policy matters rather than to learn whether Jane Fonda or the NRA contributed to the candidate's campaign. ${ }^{150}$

Our proposed regime of mandated anonymity could accommodate the voters' interest in donor identity in two ways, which we call "mandated partial disclosure" and "optional partial disclosure." Mandated partial disclosure would require a blind trust to publicly report the identity of all donors, together with the amounts that they had contributed up to the threshold anonymity level of $\$ 200 . .^{151}$ Optional partial disclosure would give the donor the

148. Undue media influence could threaten the effectiveness of many public financing schemes. If public finance is based on mass opinion-for example, in the form of voucher contributions-then controlling the organs of mass communication may continue to give print and broadcast reporters inordinate power. The argument that private contributions could provide a counterweight for media manipulation is strong enough that we favor allowing private contributions to supplement public finance. We would control the corrupting influence of such contributions by mandating donor anonymity. See text accompanying notes 164-168 infra (discussing why private contributions should be allowed to supplement a nonexclusive program of public finance).

149. Buckley v. Valeo, 424 U.S. 1, 67 (1976) (per curiam).

150. However, we can imagine contexts in which individual donors may have better information-possibly based on private conversations with the candidates-about a candidate's future behavior than could be gleaned from the public record. Our point is merely that government's interest in voter information is less compelling than its interest in deterring corruption.

151. Thus, if Jones donated $\$ 1000$ to Clinton, the blind trust would publicly report that Jones had donated at least $\$ 200$. If Smith donated $\$ 100$, the trust would report that Smith had donated $\$ 100$. 
option of disclosing her identity and contribution (up to $\$ 200$ ). ${ }^{152}$ The benefit of mandated partial disclosure is that it provides voters with an irreducible amount of donor information. The drawback is that it burdens donors' free speech interests. Under a Pat Buchanan presidency, for example, mandated partial disclosure might deter donations to a NARAL PAC or EMILY's List. Optional partial disclosure reduces the burden on donors' free speech rights by giving donors the option to remain completely anonymous.

We prefer optional partial disclosure. It is clearly the more constitutionally sound of these two methods to implement a broader system of donor anonymity. ${ }^{153}$ And given some donors' interest in making their contributions public, we predict that the vast majority of donors would opt for partial disclosure. Given that voter knowledge of donor identity is less important in a regime in which candidates as well as voters are kept in the dark, and given the information that would be generated under a system of optional partial disclosure, the public's interest in donation information does not ultimately militate against our proposed anonymity regime.

\section{Less donor information for PAC contributors.}

Finally, mandated anonymity will make it more difficult for donors to monitor how PACs and other political intermediaries spend their money. Under our proposed system, PACs would only have the option of disclosing a donation of $\$ 200^{\circ}$ or less to any one candidate. Prospective PAC donors would have more difficulty assessing whether the PAC had served their interests effectively.

For those who think PAC influence is a destructive force in our polity, disrupting donors' ability to monitor PACs is all to the good because potential PAC donors who are unable to monitor are less likely to contribute. One might argue that mandated anonymity goes too far in impeding the ability of insular groups to organize and influence government. As David Strauss has observed, "The question of how responsive a representative should be to the electorate is notoriously difficult, and it is not clear that the greater responsiveness that comes from allowing contributions will make matters worse."154

152. Thus, if Jones donated $\$ 1000$ to Clinton, the donor would have the option of deciding whether her entire gift would be anonymous or whether the trust would publicly report that she had donated at least $\$ 200$. For convenience, we might establish a partial disclosure default, presuming that the trust would partially disclose unless the donor explicitly opted for anonymity.

153. In Buckley, the Court held that the mandated disclosure requirements of FECA were constitutional, see id. at 143, but noted that "compelled disclosure, in itself, can seriously infringe on privacy of association and belief guaranteed by the First Amendment," id. at 64. A system of optional disclosure would be more likely to withstand a First Amendment challenge.

154. Strauss, supra note 28 , at 1377. 
But while we acknowledge these potential harms, we also believe their effect is relatively minor. First, prohibiting bundling substantially reduces the difference between the maximum allowable contributions and the maximum disclosed contribution. Instead of bundling together tens or hundreds of thousands of dollars for individual candidates, a PAC's annual contributions to any individual candidate are limited to the legal cap of $\$ 5000 .{ }^{155}$ Because $\$ 200$ of the PAC's contributions will be publicly reported, PAC donors would only be uncertain about the remaining $\$ 4800 .^{156}$ Second, restricting PAC donor information is unlikely to disrupt PAC formation because most PAC donors don't avail themselves of this information. ${ }^{157}$ Most donors give to Newt Gingrich's leadership PAC, for instance, because they trust his ideological and political instincts, not because they have microanalyzed the effectiveness of the way in which his PAC allocates its contributions. Mandated anonymity might disrupt PACs because donors would not be as willing to donate to an organization that can no longer corrupt/influence politicians, but this effect is a benefit rather than a cost of our proposal.

\section{Is Mandated Anonymity Better Than Alternative Reforms?}

Up to this point, we have tried to show that requiring anonymous donations would be better-even conceding the aforementioned problems-than the status quo. However, to be persuasive, we must also show that mandated anonymity is better than alternative reforms or that it should at least be implemented as part of a broader reform package.

We concede that it might be appropriate to combine a regime of mandated anonymity with increased public finance because anonymity will not completely eliminate the effects of donor wealth inequality and because anonymity might cause a sharp reduction in the overall level of political contributions. Initially, we might think that public funding eliminates the need for anonymity regulation: If the government is the only donor, then there should be no opportunity for private corruption. However, there are several reasons why enlightened systems of public finance should include elements of mandated anonymity.

First, public campaign subsidies should not completely displace private contributions. We thus reject the exclusivity dimension of both the Patriot

155. See 2 U.S.C. $\$ 441 \mathrm{a}(\mathrm{a})(2)$ (1994).

156. The difference between the actual contribution and the disclosed amount would probably be even smaller under a system of mandated anonymity because giving more than $\$ 200$ will purchase no additional PAC influence.

157. Cf. Joseph P. Kalt \& Mark A. Zupan, Capture and Ideology in the Economic Theory of Politics, 74 AM. ECON. REV. 279, 283 (1984) (noting that "voter-owners," like PAC donors, "have poor incentives to be well-informed"). 
dollar and Clean Money proposals, whereby candidates who agree to take public funding would have to forego all private contributions. ${ }^{158}$ Completely excluding private contributions in favor of public funding based on expressions of support by broad constituencies can constrain voters' exposure to innovative or unpopular ideas. In a privately financed system, lesser-known challengers might be able "to raise funds through a more limited number of extremely generous donors." 159 But a regime of exclusive public financeincluding one requiring candidates to make an all-or-nothing choice between public or private finance-may prevent such candidacies from getting off the ground. 160 Moreover, as discussed above, ${ }^{161}$ public-funding schemes that prohibit private contributions exacerbate the influence of the media by affording them an inordinate role in determining how the public funds will be allocated and filling the void left by private contributors.

Instead of making an all-or-nothing choice between the failings of public and private finance, it is better to create a mixed system in which the public and private spheres can each correct the failings of the other. ${ }^{162}$ Bruce Ackerman is right to reject the "brute property" argument that a citizen should be free to contribute as much of her money as she wants. ${ }^{163}$ But a nonexclusive system of public finance better accommodates both the private and public sectors by creating a system of checks and balances. This is particularly true when large contributions are funneled through blind trusts. Mandated anonymity will as a de facto matter eliminate the worst excesses of private donations while providing some opportunity for private donations to mitigate problems of public funding.

Second, even if public finance becomes the exclusive means of funding campaigns, we would still need mandated anonymity to constrain soft money and independent expenditure corruption. ${ }^{164}$ Public finance reforms would be

158. See Ackerman, supra note 3, at 71; Donnelly et al., supra note 15, at 6 ("Candidates who choose to enter into the Clean Elections Option must agree . . . to refuse all private contributions once the public money comes in.").

159. Sunstein, supra note 15, at 1403 n.47 (citing Stephen E. Gottlieb, The Dilemma of Election Campaign Finance Reform, 18 HOFSTRA L. REV. 213, 221 (1989)).

160. See Hasen, supra note 55, at 43 ("Consider the extreme case: an individual with unpopular political ideas is prevented from spending her own money to run for federal office. To the extent that money facilitates speech, the voucher plan will stifle an unpopular political view.").

161. See text accompanying notes 146-147 supra.

162. See generally IAN AYRES \& JOHN BRAITHWAITE, RESPONSIVE REgulation: TRANSCENDING THE DEREGULATION DEBATE (1992) (proposing a mixed scheme in which privately and publicly determined prices can reduce the risk of capture and collusion within an industry); Ian Ayres \& John Braithwaite, Partial-Industry Regulation: A Monopsony Standard for Consumer Protection, 80 CAL. L. REV. 13 (1992) (setting forth the same proposal).

163. See Ackerman, supra note 3, at 78.

164. In addition, if candidates have a choice of whether to forego private contributions in exchange for public finance, a mandated anonymity requirement would be appropriate for those candidates who opt out of public funding. 
hard pressed to prohibit political parties from accepting private contributions-particularly after the Supreme Court's recent decision in Colorado Republican Federal Campaign Committee v. FEC ${ }^{165}$ exempting political parties from limits on independent expenditures. ${ }^{166}$ Requiring blind trusts to funnel all contributions to political parties would be particularly important under a system of exclusive public funding. It would deter private contributors from end running the system by contributing soft money to their candidate's party. Indeed, the most important application of the anonymity idea may concern independent expenditures. As discussed above, ${ }^{167}$ requiring that independent (express advocacy) expenditures be funded through blind trusts may dampen the shift from direct contributions that might be induced by any campaign restriction.

Third, mandated donor anonymity would also be necessary under any voucher system of public finance, particularly to restrain PACs and other voucher intermediaries from corruptly exchanging vouchers for influence. ${ }^{168}$ As Vince Blasi has noted, "[PAC] brokering and bundling would probably continue under a voucher system; at least two major proponents of campaign finance vouchers [Ackerman and Foley] expect and hope that it would. PACs might deal in vouchers the way they now deal in money."169 But requiring PACs and other voucher intermediaries to contribute their voucher aggregations anonymously can deter the worst types of quid pro quo and monetary influence corruption while preserving the egalitarian benefits of vouchers.

Finally, mandated anonymity has one important advantage over many other proposals: It is more clearly constitutional. ${ }^{170}$ Prohibiting all private contributions-or prohibiting candidates from spending their own money-is constitutionally suspect. This is true even if candidates "voluntarily" accept such restrictions in return for public money. ${ }^{171}$ A full, frontal assault on

165. 116 S. Ct. 2309 (1996).

166. See id. at 2312.

167. See text accompanying notes 84-95 supra.

168. For the reasons stated by Ackerman, we prefer a voucher program like Patriot dollar over more centralized public finance programs such as Clean Money. See Ackerman, supra note 3, at 72-73; see also Donnelly et al., supra note 15, at 6-7 (discussing the Clean Money proposal).

169. Blasi, supra note 113, at 1321; see also Ackerman, supra note 3, at 74 (arguing that voters should be allowed to transfer their voucher funds to PACs); Foley, supra note 35, at 1208 (proposing an "equal-dollars-per-voter" system in which PAC donations come in the form of vouchers, which, like money donations, could still be bundled and passed on to another PAC).

170. We consider the constitutionality of our core mandated anonymity proposal in the next section. See text accompanying notes 177-194 infra.

171. "[C]ontribution caps are permitted-but only up to a point. No contribution cap has ever been sustained except on the rationale that it advances the battle against corruption or the appearance of corruption." E. Joshua Rosenkranz, Clean and Constitutional, BOSTON REV., Apr.-May 1997, at 13; see also Kentucky Right to Life, Inc. v. Terry, 108 F.3d 637, 639 (6th Cir. 1997) (up- 
wealth inequality may prove constitutionally futile. Mandated anonymity, in contrast, is narrowly tailored to promote the government's compelling interest in deterring quid pro quo corruption, but it is also likely to substantially reduce the influence of unequal wealth.

The fear that any campaign finance regulation would lead to an unacceptable shift from candidate support to "issue advocacy," "independent expenditures," or both has led to a legislative proposal of Representative John Doolittle: The Citizen Legislature and Political Freedom Act. ${ }^{172}$ This finance reform "essentially would repeal the limits on political campaign contributions, require immediate disclosure by candidates when they do receive contributions [and] require the Federal Election Commission to post all the reports on the Internet."173 This proposed reform has garnered support from a wide spectrum of both liberal and conservative scholars. ${ }^{174}$

But this quasi-libertarian proposal must implicitly assume that disclosure will not have much of a deterrent effect. If disclosure deters corrupt direct giving, these proponents would have to fear that the same corrupt contributions would reappear as indirect giving (a.k.a. "issue advocacy"), where donor disclosure is not required. ${ }^{175}$ Proponents of mandated disclosure must admit either that finance regulation can sometimes deter unwanted direct contributions without creating an unacceptable substitution or that mandated disclosure is simply window dressing which is not really expected to deter unwanted contributions.

Maybe the most important implication of our mandated anonymity proposal is that it has forced us to rethink whether mandated disclosure can be defended. ${ }^{176}$ In the end, reasonable people might reject the donation booth because of the likely increase in issue advocacy expenditures. If our proposal induces even a partial shift of contributions toward reckless and unaccountable speech, we might not want to extend the voting booth rationale to campaign finance. But mandated disclosure regimes-if effective-should give rise to similar hydraulic effects. It is difficult to advance a priori argu-

holding a Kentucky law imposing contribution caps on individuals and PACs to combat widespread corruption among political officials).

172. See Pete du Pont, Campaign Finance Defies a Complicated Solution, TAMPA TRR., Sept. 7,1997 , at 6 .

173. Id.

174. See, e.g., Kathleen M. Sullivan, Political Money and Freedom of Speech, 30 U.C. DAVIS L. REV. 663, 688-89 (1997); du Pont, supra note 172, at 6.

175. See Sullivan, supra note 174, at 690 ("[C]ompelled disclosure avoids a regime of absolute laissez-faire. Even this partial deregulation might have unintended consequences.").

176. It is interesting to contrast the pure disclosure regime-exemplified by the Doolittle proposal-with a pure anonymity regime, in which mandated anonymity was the only regulation. Neither system should truly satisfy a libertarian because donors in these regimes would be forced to either speak or remain silent. But our mandated anonymity regime arguably grants the donor more liberty, since it gives the donor the option to signal at least a \$200 donation credibly. 
ments against mandated anonymity while at the same time advancing a priori arguments in favor of mandated disclosure.

The donation booth is not a substitute for-but a complement tomonetary campaign restrictions. We would retain the contribution limits currently established by FECA and would increase the availability of public funding by way of a voucher program. But at this point, we hope we have persuaded the reader that the idea of a donation booth-while not a panacea-is useful either by itself or as part of a larger reform package.

\section{CONSTITUTIONAL AND POLITICAL FEASIBILITY}

\section{A. Constitutional Feasibility}

The purpose of this section is to show that our proposed regime of mandated anonymity is clearly constitutional. To do this, we analyze the burden that our proposal imposes on donors' free speech interests and argue that this burden is marginal compared to the government's compelling interest in reducing corruption. ${ }^{177}$

In locating the exact burden, we should begin by remembering what our proposal does not do. It does not affect how much a donor can contribute, and it does not limit the words a donor might say. Our regime would even allow a donor to prove she had given up to $\$ 200$. The only burden of our anonymity proposal is that donors could not credibly signal that they had given more than $\$ 200$. The inability to prove a large contribution certainly burdens a donor's ability to communicate. Reducing the "expressive value" of a contribution might deter some large donors from giving. 178

However, the Supreme Court's jurisprudence suggests that the size of this burden is rather marginal, particularly because donors can prove they contributed $\$ 200$. In discussing the burden of contribution limits, the Court in Buckley found that

a limitation upon the amount that any one person or group may contribute to a candidate or political committee entails only a marginal restriction upon the contributor's ability to engage in free communication. A contribution serves as a general expression of support for the candidate and his views, but does not communicate the underlying basis for the support. The quantity of communication by the contributor does not increase perceptibly with the size of his contribution, since the expression rests solely on the undifferentiated, symbolic act

177. The Court's approach to free speech claims is to balance the speaker's burden against the government's interest. See, e.g., Buckley v. Valeo, 424 U.S. 1, 64-65 (1976) (per curiam) (discussing the requirement that the government's interest in limiting First Amendment rights "survive exacting scrutiny").

178. "A contribution ... also has an expressive value, in the sense that people might value the opportunity to affirm their views by making a contribution even if the contribution is very unlikely to have any effect on outcomes." Strauss, supra note 28, at 1383. 
of contributing. ... A limitation on the amount of money a person may give to a candidate or campaign organization thus involves little direct restraint on his political communication, for it permits the symbolic expression of support evidenced by a contribution but does not in any way infringe the contributor's freedom to discuss candidates and issues. ${ }^{179}$

This analysis suggests that a donor's burden of proving that she gave Clinton $\$ 1000$ instead of $\$ 200$ should be considered only "a marginal restriction upon the contributor's ability to engage in free communication." The quantity of communication involved in proving that a donor gave a larger amount "does not increase perceptibly." And the effect of the restriction is mitigated by the donor's unrestricted ability to speak independently in favor of a particular candidate.

Indeed, our proposed regulation might even be less burdensome than the current FECA regulations that have passed constitutional muster. Our regime of mandated anonymity - while imposing the "marginal" burden of not permitting a donor to prove she gave more than $\$ 200$-removes the current burden of having to disclose gifts over $\$ 100 .{ }^{180}$ Thus, properly understood, the net change in the First Amendment burden of moving from the current system of mandated disclosure to a system of mandated anonymity is, at most, a de minimus increase. It might even be seen as a decrease because our proposed regime would give donors the option of saying anything and proving up to $\$ 200$ of giving. This slight burden is constitutionally justified by the government's compelling interest in "preventing corruption or the appearance of corruption."181

The constitutionality of our mandated anonymity proposal can most clearly be demonstrated by comparing the constitutional costs and benefits of our proposal to two other free speech restrictions that have passed constitutional scrutiny: compelled disclosure of donor identity (reporting require-

179. Buckley, 424 U.S. at 20-21.

180. See 2 U.S.C. $\S 434($ e) (1994). As described below, our proposal would give donors of any amount the option to contribute anonymously. See text accompanying notes 152-153 supra.

181. FEC v. National Conservative PAC, 470 U.S. 480,496 (1985). In National Conservative $P A C$, the Supreme Court reaffirmed its holding in Buckley that "preventing corruption or the appearance of corruption are the only legitimate and compelling government interests thus far identified for restricting campaign finances." Id. at 496-97. However, this summation is a little misleading because

some of the Court's decisions allow measures that seem to be directed at inequality. . . . For example, in Austin v. Michigan Chamber of Commerce, 494 U.S. 652 (1990), which upheld a restriction on campaign-related expenditures, the Court asserted that the restriction was concemed with "corruption" but defined "corruption" in a way that made it essentially equivalent to inequality.

Strauss, supra note 28, at 1369 \& n.1; see also Austin v. Michigan State Chamber of Commerce, 494 U.S. 652, 659-60 (1990) ("Michigan's regulation aims at a different type of corruption in the political arena: the corrosive and distorting effects of immense aggregations of wealth that are accumulated with the help of the corporate form and that have little or no correlation to the public's support for the corporation's political ideas."). 
ments) and mandated anonymity of voters (secret balloting). By showing that mandated anonymity is less burdensome and more supportive of the government's interest in preventing corruption, these comparisons provide two a fortiori arguments for the constitutionality of anonymity regulation.

First, the Supreme Court's willingness in Buckley to approve of compelled disclosure of donor identity suggests that compelled nondisclosure is all the more constitutional. Mandated nonanonymity is more burdensome than mandated anonymity. 182 Mandated disclosure may deter potential donors from giving to unpopular causes for fear of retaliation or ostracism; ${ }^{183}$ in comparison, the chilling effect on those legitimate donors who want to prove they gave more than $\$ 200$ should be considered only a secondary concern. In addition, mandated disclosure is less likely to further the government's interest in preventing corruption. Even though the Supreme Court suggested that mandated disclosure could deter corruption, ${ }^{184}$ it has proved exceedingly difficult to prove either quid pro quo or monetary influence corruption from the mere knowledge of identity. As adumbrated in Part I, donor anonymity is more likely to deter corruption because uninformed candidates have less opportunity to peddle influence or change their positions in the hope of garnering greater contributions. ${ }^{185}$

182. Speaking more broadly, the right to silence or anonymity enjoys more protection than the right to speak credibly. Plenty of cases can be found where the Supreme Court has struck down regulations requiring speakers to identify themselves. See, e.g., McIntyre v. Ohio Elections Comm., 514 U.S. 334, 353 (1995) (striking down an Ohio statute that prohibited the distribution of anonymous campaign literature as a violation of the First Amendment); Talley v. California, 362 U.S. 60, 66 (1960) (striking down a city ordinance that forbade the distribution of anonymous handbills). But it's hard to find cases where the First Amendment has been abridged because a statute won't allow a speaker to prove what he says is true. Indeed, the strong antilibel impulse enunciated by Justice Hugo Black and others makes it harder for speakers to signal the truth of their allegations credibly because false statements often do not expose the speaker to monetary damages. If, instead, we thought that a vibrant free speech right protects speakers' ability to stand behind their words, we might conclude that the First Amendment requires speakers to have at least the option to expose themselves to libel liability. See Ian Ayres, Empire or Residue: Competing Visions of the Contractual Canon, in LEGAL CANONS (J.M. Balkin \& S. Levinson eds., forthcoming 1998).

183. See Seth F. Kreimer, Sunlight, Secrets, and Scarlet Letters: The Tension Between Privacy and Disclosure in Constitutional Law, 140 U. PA. L. REV. 1, 35-54 (1991) (discussing the retaliation and ostracism resulting from McCarthy era mandatory disclosures of unpopular exercises of constitutional rights).

184. In Buckley, the Court found that

[mandating disclosure] may discourage those who would use money for improper purposes either before or after the election. A public armed with information about a candidate's most generous supporters is better able to detect any post-election special favors that may be given in return. And, as we recognized in Burroughs v. United States, 290 U.S., at 548, Congress could reasonably conclude that full disclosure during an election campaign tends "to prevent the corrupt use of money to affect elections."

Buckley, 424 U.S. at 67.

185. The First Amendment requires not only that the effect of furthering the government's compelling interest outweigh the speech burden, but that government choose the least restrictive altermative for achieving its compelling interest. See Central Hudson Gas \& Elec. Corp. v. Public 
Second, the constitutionality of the voting booth-i.e., mandated voting anonymity-suggests that mandated donor anonymity is also constitutional. The voting booth also burdens political expression. No matter how much a conservative wants, she can never prove she did not vote for McGovern, nor can a liberal prove he did not vote for Reagan. ${ }^{186}$ Since voting is the quintessential act of political expression, denying citizens the right to prove for whom they voted is surely more burdensome than denying citizens the right to prove they gave a candidate more than $\$ 200 .{ }^{187}$

Although the privacy of the voting booth is an innovation of less than 100 years' standing, we cannot conceive that the Supreme Court would strike down this form of mandated anonymity as unduly burdening voters' free speech rights. Opponents of mandated donor anonymity will be hard pressed to explain why a donation booth is unconstitutional, but a voting booth is not.

Ackerman's "brute property" argument ${ }^{188}$ correctly identifies a deeply held impulse in our polity: "It's my property and I have a right to use it to support any candidate I want." The donation booth accommodates this impulse while simultaneously restraining property's influence. The donation booth does not affect how property can be used, nor does it limit the words (or other signals) a donor may employ to describe her use. But because the ability to prove credibly how one uses her property is not a firmly established concomitant of ownership, the donation booth does not directly contradict the "brute property" impulse.

While the foregoing arguments dispose of any constitutional challenge based on donors' free speech rights, the possibility that mandated anonymity would severely limit candidates' ability to raise money poses additional con-

Serv. Comm'n of N.Y., 447 U.S. 557 (1980). See generally Eugene Volokh, Freedom of Speech, Permissible Tailoring and Transcending Strict Scrutiny, 144 U. PA. L. REv. 2417 (1996). Even though Buckley does not discuss this additional "least restrictive alternative" requirement in constitutionalizing mandated disclosure, Buckley, 424 U.S. at 67, we have shown that mandated anonymity is less restrictive than mandated disclosure and hence more consistent with this additional constitutional requirement.

186. The secret ballot may also disadvantage racial minorities. African American candidates often fare better in polls taken on the eve of an election, and even in exit polls, than they do in the actual elections, where the anonymity of the voting booth is available. See Levmore, supra note 4, at 2223. Forcing whites to vote in public might, for example, deter anonymous racism. See Lynn A. Baker, Direct Democracy and Discrimination: A Public Choice Perspective, 67 CHI.-KENT L. REV. 707, 733-34 (1991) (discussing the possibility that open voting in a plebiscite might advantage racial minorities).

187. The government's interest in preventing vote as compared to donation corruption cannot easily explain why the voting booth would stand on a firmer constitutional footing than the donation booth. The danger of donation corruption is greater than the danger of voting corruption because wealth is much more concentrated than votes. The transaction costs of vote corruption are much higher because candidates would need to cut deals with many more people for vote corruption to have an effect.

188. See Ackerman, supra note 3, at 78 ("[I]t's my money. Why can't I spend it on ... a candidate...?"). 
stitutional concerns. ${ }^{189}$ Buckley, in discussing contribution limits, found that, "[g]iven the important role of contributions in financing political campaigns, contribution restrictions could have a severe impact on political dialogue if the limitations prevented candidates and political committees from amassing the resources necessary for effective advocacy." 190 Requiring donor anonymity might analogously impede political dialogue by reducing the number of large contributions. However, it is unlikely that a facial challenge to our proposal on this basis would succeed. In upholding contribution limits, the Buckley Court found that

[t] he overall effect of the Act's contribution ceilings is merely to require candidates and political committees to raise funds from a greater number of persons and to compel people who would otherwise contribute amounts greater than the statutory limits to expend such funds on direct political expression, rather than to reduce the total amount of money potentially available to promote political expression. ${ }^{191}$

The ability to raise funds from smaller donors and the ability of large donors to speak independently also mitigate the impact of mandated anonymity. ${ }^{192}$ Moreover, the Constitution doesn't require Congress to facilitate

189. In Part II.C, we also discussed the information problems for voters and PAC donors. But neither of these problems raises serious constitutional issues. Even though the Supreme Court identified voter information as one of the government interests furthered by mandated disclosure, it would be inconsistent with Supreme Court precedent to suggest that this state interest makes mandatory disclosure (or even optional disclosure) constitutionally required. See Buckley, 424 U.S. at 67.

The possibility that our proposal would impede the ability of PACs to operate by making it more difficult for PAC donors to monitor how their contributions were spent could give rise to an associational challenge. As discussed in Buckley, "[G]roup association is protected because it enhances '[e]ffective advocacy.' The right to join together 'for the advancement of beliefs and ideas,' is diluted if it does not include the right to pool money through contributions, for funds are often essential if 'advocacy' is to be truly or optimally 'effective." Buckley, 424 U.S. at 65-66 (citations omitted); see also NAACP v. Alabama ex rel. Patterson, 357 U.S. 449, 460-61 (1958) ("[A]ction which may have the effect of curtailing the freedom to associate is subject to the closest scrutiny.").

While mandated anonymity poses some risk of curtailing the freedom to associate, our previous analysis suggests that the effect on legitimate associational efforts should be slight. See text accompanying notes 143-157 supra. Few PAC donors currently take advantage of available information. Our proposal would allow PAC donors to continue to monitor up to $\$ 200$ of PAC contributions to each candidate. Moreover, if the threat of rent extraction, see text accompanying notes 26-27 supra, is currently keeping some PACs from forming, mandated anonymity might even facilitate important forms of group association. Finally, disrupting illegitimate or corrupt associational efforts should not count against the proposal: Disrupting the ability of criminals to conspire does not raise constitutional concerns.

190. Buckley, 424 U.S. at 21 . The fact that mandated anonymity only indirectly restrains giving-as opposed to the direct restraints of contribution limits-does not eliminate the constitutional concern: "[Exacting] scrutiny is necessary even if any deterrent effect on the exercise of First Amendment rights arises, not through direct government action, but indirectly as an unintended but inevitable result of the government's conduct in requiring disclosure." Id. at 65 .

191. Id. at 21-22.

192. Even though Buckley gave rather short shrift to the associational burdens of contribution limits, at times the Supreme Court has shown much more hostility to laws that create financial dis- 
corruption in order to subsidize political speech. Prohibiting quid pro quo deals might also substantially reduce the ability of candidates to speak, but the First Amendment doesn't mandate generating money to produce a meaningless debate in which donors have already purchased candidates' positions outside the realm of open deliberation.

Constitutional concerns about reducing the overall quantity of political expression could also be alleviated by combining our proposal with an expanded program of public finance. If candidates opted to funnel all private contributions through a blind trust system in return for expanded public funding, it would be more difficult to argue that political expression had suffered. Indeed, the most minimal version of our proposal would simply give candidates the option of donor anonymity without the carrot of any additional funding. ${ }^{193}$

Finally, it should be remembered that several jurisdictions have recently experimented-and a few continue to experiment-with mandated donor anonymity in judicial elections. Like mandated voting anonymity, the mandated donor anonymity in judicial elections has never been successfully challenged. ${ }^{194}$

\section{B. Political Feasibility}

Cynics will argue that any worthwhile reform has no chance of being enacted. We share this pessimism. Any system that is effective in reducing the current amounts of quid pro quo and monetary influence corruption is bound to gore some political ox. We predict, for example, that the incumbent chairs of powerful congressional committees would be disadvantaged by our proposal-because a large proportion of their "access" money would dry upand therefore they would be inclined to oppose it. ${ }^{195}$

incentives for speaking. For example, in Simon \& Schuster, Inc. v. Members of New York State Crime Victims Board, 502 U.S. 105 (1991), the Supreme Court struck down New York's "Son of Sam" law, which required that "an accused or convicted criminal's income from works describing his crime be deposited in an escrow account." Id. at 108. And in United States v. National Treasury Employees Union, 513 U.S. 454 (1995), the Court held that Congress could not prohibit honoraria for speeches and articles by low-level executive employees. See id. at 457.

193. See text accompanying notes 200-202 infra.

194. This may, however, be a function of lax enforcement. Indeed, in the only case against a judge for violating the donor anonymity requirement, there were broad constitutional challenges which the reviewing court rejected as unripe. Nicholson v. State Comm'n on Judicial Conduct, 422 N.Y.S.2d 701, 704 (N.Y. App. Div. 1979).

195. The powerful people in Congress benefit directly from additional campaign contributions and indirectly through control of "leadership PACs," which can dole out contributions to less powerful legislators in return for votes and legislative activity. See Mike Dorning, PACs Are Key Path to Clout in Congress: Lawmakers Hand Cash to Colleagues' Campaign Funds, CHI. TRIB., July 16, 1997, at 1 (noting that "at least 47 sitting members of Congress have set up 'leadership' political action committees" to build up war chests for their parties). 
On the other hand, incumbents will probably have an easier time inferring the identity of their current contributors based on longer-term relationships and histories of past giving. It may be more difficult for a newcomer who runs for the first time behind a financial veil of ignorance to distinguish the real from the faux contributors. So it is possible that mandated anonymity could even enhance the relative disparity between the ability of incumbents and nonincumbents to raise funds.

Some incumbents might even relish the additional independence that mandated anonymity would foster. Aspects of the current system force candidates into a competitive rat race in which they feel compelled to continually lower their ethical standards to keep up with their adversaries. Democrats, for example, have repeatedly defended their efforts to raise soft money as necessary to keep parity with the Republicans' burgeoning coffers. ${ }^{196}$ Mandated anonymity might reduce the intensity of the fundraising marathon that modern politics has become. ${ }^{197}$

Nonetheless, we think that the impetus for any meaningful reform-including mandated anonymity-needs to come from outside the beltway. If reform is to have a chance, a fresh round of scandals needs to mobilize the nation's conscience. ${ }^{198}$ Recall how FECA arose out of the debris of Watergate. But as we write this in September 1997, the time may have already passed for the initial outrage over 1996 campaign abuses to motivate Congress to act.

Rent extraction-or, less euphemistically, the extortion of contributions by threatening unfavorable government action-might induce corporate and other organized interests to favor mandated anonymity. The donation booth would stop incumbents from shaking down deep-pocket organizations. ${ }^{199}$ Indeed, an expanding group of CEO's has pledged not to give soft money to either political party. ${ }^{200}$ Our proposal helps institutional donors by removing the political pressure to give (or else). Thus, one small ray of hope for mandated donor anonymity is that this reform might draw on a broader spectrum

196. See Donnelly et al., supra note 15 , at 3 .

197. See Steve Piacente, Senator Rejects Hollings' Cure, POST \& COURIER (Charleston, S.C.), Mar. 19, 1997, at 1 ("To remain competitive, [Senator Barbara] Boxer said, she must raise $\$ 10,000$ a day, seven days a week, for six straight years."); see also text accompanying notes 73-75 supra.

198. While not rising to the level of a "constitutional moment," BRUCE ACKERMAN, WE THE PEOPLE: FOUNDATIONS 267 (1991), a crisis must at least mobilize ordinary people to take action that is beyond their narrow self-interest. See ALBERT O. HIRSCHMAN, SHIFTING INVOLVEMENTS: PRIVATE INTERESTS AND PUBLIC ACTION 3 (1982) ("[O]ur societies are in some way predisposed toward oscillations between periods of intense preoccupation with public issues and of almost total concentration on individual improvement and private welfare goals.").

199. Individual corporations may not want to lead the impetus for mandated anonymity, however, because doing so would strongly signal that they intend to reduce their donations.

200. See Mahoney, supra note 29 , at A14. 
of political support than proposals that undermine the ability of private interests groups to organize.

At a minimum, Congress should change the law to give individual candidates the option of using blind trusts to finance their campaigns. ${ }^{201}$ The first question candidates should be asked when they announce their candidacy is whether they will commit to donor anonymity. We hope that candidates would voluntarily comply in order to avoid explaining why they need to know the identity of their donors. But we fear the issue can be demagogued. Opponents of mandated anonymity are likely to respond, "What do the proponents have to hide? Why aren't they willing to reveal who their contributors are?" Of course, these same questions were asked of those early proponents of the secret ballot. Nonetheless, we worry that the anonymity rationale will seem too subtle when applied to the problem of campaign finance. Scholars almost never candidly assess the chances that their legislative proposals will be enacted. To admit a small probability somehow seems to undermine the claim that the proposal is worthwhile. While it pains us, we think the donation booth faces an uphill battle.

\section{CONCLUSION}

The dominance of the disclosure idea is captured by Justice Brandeis' famous words (admiringly quoted in Buckley): "Publicity is justly commended as a remedy for social and industrial diseases. Sunlight is said to be the best of disinfectants; electric light the most efficient policeman."202

201. If opting for anonymity is a way for candidates to indicate that they are not going to be influenced by their contributors, one might reasonably wonder why more candidates have not already found a way to remain uninformed. Jerry Brown opted for effective anonymity by refusing to accept single contributions over \$100. See Michael Kranish, Powell's Bottom Line: Swift Decision Required, BOSTON GLOBE, Nov. 8, 1995, at 1 ("In 1992, Brown raised $\$ 9.4$ million, including federal matching funds, while limiting contributions to $\$ 100$ per individual and setting up a toll-free number for donations."); text accompanying note 5 supra (noting that small donations are effectively anonymous). Short of refusing large contributions, it is currently impossible for a candidate to opt credibly for ignorance. Disclosure laws require a candidate to become informed. To give candidates a credible option, government would not only need to amend these laws, but also to create a mechanism, such as the one outlined in Part II.A, that would certify to voters that anonymity was maintained.

202. Buckley v. Valeo, 424 U.S. 1, 67 (1976) (per curiam) (quoting L. BRANDEIS, OTHER PEOPLE'S MONEY 62 (Nat'l Home Library Found. ed., 1933)); see also id. at 67 n.79 ("[I]nformed public opinion is the most potent of all restraints upon misgovernment." (quoting Grosjean v. American Press Co., 297 U.S. 233, 250 (1936))).

As it turns out, "electric light" may not be "the most efficient policeman." Mandating that potential victims take hidden precautions might be more effective than disclosing their precautions in stopping crime. Turning on an electric light in front of your house may simply shift crime toward your unlit neighbors, whereas installing a silent alarm might help to reduce crime throughout the neighborhood because burglars will be discouraged from stealing generally. See Ian Ayres \& Steven D. Levitt, Measuring the Positive Externalities from Unobservable Victim Precaution: An 
Congress' goal in enacting FECA was to achieve "full disclosure."203 And today a growing number of politicians are embracing immediate disclosure-possibly across the Internet-as the only effective means to discourage politicians from selling access or influence. ${ }^{204}$

This article stands against this culture of disclosure, but then again, so does the secret ballot. ${ }^{205}$ The strategy of keeping the candidate as well as the public in the dark has a long pedigree. Maimonides long ago extolled the benefits of anonymous charity. ${ }^{206}$ We should remind ourselves why we chose to make voting a solitary act. Indeed, anyone opposing mandated donor anonymity needs to explain why we shouldn't also jettison mandated voting anonymity. The donation booth is not a panacea, but it keeps faith with the simple and widely held belief that the size of your purse should not determine your access to government.

Empirical Analysis of Lojack, 113 Q.J. ECON. 43, 43 (1998) (finding that a $\$ 500$ investment in hidden precaution reduces fellow citizens' expected theft loss by $\$ 5000$ ).

203. Buckley, 424 U.S. at 78.

204. See text accompanying notes 172-176 supra.

205. Saul Levmore and Michael Fitts have written two other articles exploring the potential benefit of anonymity over disclosure. See generally Michael A. Fitts, Can Ignorance Be Bliss? Imperfect Information As a Positive Influence in Political Institutions, 88 MICH. L. REV, 917 (1990); Levmore, supra note 4.

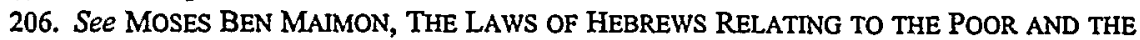
STRANGER 67-68 (James W. Peppercome trans., Pelham Richardson 1840) (exalting charitable gifts, including those that are anonymous). 
HeinOnline -- 50 Stan. L. Rev. 892 1997-1998 